Article

\title{
Investigation of the Influence of Different Vegetable Oils as a Component of Blended Biofuel on Performance and Emission Characteristics of a Diesel Engine for Agricultural Machinery and Commercial Vehicles
}

\author{
Vladimir Markov ${ }^{1}$, Vyacheslav Kamaltdinov ${ }^{2} \mathbb{D}$, Sergey Devyanin ${ }^{3}$, Bowen Sa ${ }^{1, *} \mathbb{C}$, Anatoly Zherdev ${ }^{1}$ \\ and Viktor Furman 4 \\ 1 Power Engineering Faculty, Bauman Moscow State Technical University, 105005 Moscow, Russia; \\ vladimir.markov58@yandex.ru (V.M.); azherdev@bmstu.ru (A.Z.) \\ 2 Department of Internal Combustion Engine and Automobile Electronic Systems, South Ural State University, \\ 454080 Chelyabinsk, Russia; vkamaltdinov@yandex.ru \\ 3 Department of Tractors and Automobiles, Russian State Agrarian University- \\ Moscow Timiryazev Agricultural Academy, 127550 Moscow, Russia; devta@rambler.ru \\ 4 Design and Production Enterprise "Dieselautomatika", 410017 Saratov, Russia; dizavt@overta.ru \\ * Correspondence: bowensa@yandex.ru; Tel.: +7-926-344-28-32
}

Citation: Markov, V.;

Kamaltdinov, V.; Devyanin, S.; Sa, B.; Zherdev, A.; Furman, V. Investigation of the Influence of Different Vegetable Oils as a Component of Blended Biofuel on Performance and Emission Characteristics of a Diesel Engine for Agricultural Machinery and Commercial Vehicles. Resources 2021, 10, 74. https://doi.org/10.3390/ resources10080074

Academic Editors: Ben McLellan and Michela Costa

Received: 26 June 2021

Accepted: 20 July 2021

Published: 22 July 2021

Publisher's Note: MDPI stays neutral with regard to jurisdictional claims in published maps and institutional affiliations.

Copyright: (c) 2021 by the authors. Licensee MDPI, Basel, Switzerland. This article is an open access article distributed under the terms and conditions of the Creative Commons Attribution (CC BY) license (https:// creativecommons.org/licenses/by/ $4.0 /)$.

\begin{abstract}
Biofuels derived from renewable plant materials are considered promising alternative fuels to decrease emissions of ICEs. This study aimed to justify the possibility of using vegetable oils of different sources as a $10 \%$ additive in blended biofuel for diesel engines of agricultural machinery and commercial vehicles. Seven different vegetable oils were investigated. Experiments have been performed by fueling a diesel engine with blended biofuels of $90 \%$ petroleum diesel fuel and $10 \%$ vegetable oil. In the maximum power and maximum torque modes, the brake power drop was no more than $1.5 \%$, and the brake-specific fuel consumption increase was less than $4.3 \%$; NOx emissions were reduced by up to $8.3 \%$, exhaust smoke - up to $37.5 \%$, CO-up to $20.0 \%$, and unburned HC-up to $27.9 \%$. In the operating modes of the European 13-mode steady-state test cycle, the integral specific emissions of $\mathrm{HC}$ decreased by up to $30.0 \%$, integral specific emissions of $\mathrm{CO}-$ up to $15.0 \%$, and integral specific emissions of NOx-up to $16.0 \%$. The results obtained show the feasibility and rationality of using the investigated vegetable oils as a $10 \%$ additive in blended biofuel for diesel engines of agricultural machinery and commercial vehicles.
\end{abstract}

Keywords: biodiesel; emission; engine performance; vegetable oil; diesel

\section{Introduction}

The inevitable depletion of traditional fossil fuels and the adverse impacts of the burning of fossil fuels on the environment and human health prompted the search for alternative and renewable energy sources [1-9]. In this regard, a renewable and sustainable solution is to use biodiesel [1,2,10-12], which is less harmful to the environment [13] and can be directly applied to existing transport infrastructure without significant changes [4,14-18]. Therefore, biodiesel fuel can be considered as a future fuel to replace fossil fuels $[19,20]$.

Biodiesel can be used in blends with diesel fuel (DF) $[5,6,17,21-30]$, binary blends [16,21,22], ternary blends $[6,12,18,22-24]$, quaternary blends of vegetable oil biodiesel, alcohol and DF [6] or in pure form [24-26] without any modifications or configurations of diesel engines [3].

Biodiesel can be produced from many different feedstocks, including non-edible oils (such as eucalyptus oil [27], Jatropha curcas oil [1,28], carania oil [29], waste vegetable and non-edible industrial oils [20], vegetable oil refinery waste [30,31], vegetable and animal oils [13,32,33], waste tallows [23,34] and vegetable oils [3,13,20,23,35-37], fish oil [13,38], waste frying oils [13,39-41], and various alcohols [6,12,13,22,32,39]). 
Biofuels obtained from vegetable oils are of the greatest interest for use in diesel engines. For this purpose, various vegetable oils have been extensively studied: eucalyptus oil [27], Jatropha seed oil [42], Jatropha curcas oil [1,21,28,43,44], palm oil [2,7,11,26,30,40,41,44-47], algal oil [10,35], Roselle oil [47], Karanja oil [29,48], crude tall oil [49], rapeseed oil [3,5,15,17,22,24,25,37,50-56], castor oil [57-59], mustard oil [20,60-62], rice bran oil [29], soybean oil [15,16,40,41,44,51,57], curry leaf (Murraya koenigii) oil [15,16,40,41,44,51,57,63], safflower oil [3,37], grapeseed oil obtained from winery biomass waste [64], Salvia macrosiphon oil [19], Mahua (Madhuca indica) oil [21], cottonseed oil [4,44], sunflower oil [16], linseed oil $[18,61,65,66]$, corn oil $[67,68]$, rubber oil [21,69,70], blended thumba vegetable oil [71], and lemongrass oil [72].

Numerous studies have established that biodiesel has a higher cetane number [22,26,27], increased oxygen content $[19,22,24-26]$, and higher density [22,24,26] and viscosity $[22,24,26]$, but is inferior in terms of a lower calorific value [26] and compressibility [22] in comparison with DF. These properties have an impact on combustion and exhaust emissions.

It is challenging to use vegetable oils as an independent fuel due to the differences in physicochemical properties between vegetable oils and petroleum $\mathrm{DF}[1,10,14,17,21,26,52,53,65]$. In this case, problems may arise in the operation of diesel engines. These include the poor quality of fuel injection and spray processes [43,51], resulting from their high viscosity $[1,6,11,12,15,21,22,24,26,43,54,64,71]$ and high density $[6,21,22,24,26,27,35,64]$, and also carbon deposition in the engine combustion chamber [12], impairing piston ring mobility. However, Lešnik L and Biluš I [24] have experimentally shown that pure biodiesel derived from rapeseed oil and its blend with petroleum DF can be used as a substitute for petroleum DF in heavy-duty diesel engines with mechanically controlled injection systems. Using pure rapeseed oil biodiesel led to lower cylinder temperatures and pressures and a lower heat release rate, but higher brake-specific fuel consumption (BSFC) by $12 \%$ in comparison with pure petroleum DF [25]. At the same time, the higher oxygen content in biodiesels and their blends contributes to a better oxidation process in the combustion chamber and a decrease in the formation of $\mathrm{CO}$ emissions [24,25].

On the other hand, Yesilyurt MK et al. [6] do not recommend using pure vegetable oils or biodiesel in diesel engines without the addition of alcohols to reduce the high viscosity and density. Mirhashemi FS and Sadrnia H [22], based on literature analysis, recommend reducing the shortcomings of biodiesel with vegetable oils of high viscosity by using different fuels, such as gasoline, hydrogen, natural gas, biogas, various types of alcohols, and fuel additives.

Qi DH et al. [56] experimentally showed that the use of ethanol-based microemulsion fuels with the volume content of ethanol up to $30 \%$ could reduce the viscosity and density of blended biofuels, bringing them closer to DF. As a result, the onset of the combustion of the microemulsion fuel was later than that of diesel fuel; meanwhile, the peak in-cylinder pressure, peak pressure rise rate, and peak heat release rate of the microemulsion fuel were higher than those of DF [56]. With an increase in the volume content of ethanol up to $40 \%$, microemulsion fuels can be directly used in a common rail direct injection diesel engine without modifications [73]. The result is a slight increase in BSFC and brake thermal efficiencies (BTE), a decrease in smoke emissions, and an increase in NOx emissions under high engine loads [73]. Similar performance and emission characteristics were obtained by adding $10-20 \%$ alcohol to castor oil-blended DF [59]. The addition of $10 \%$ butanol to jojoba oil-blended DF reduced the viscosity of the mixture by up to $85 \%$ compared to pure raw jojoba oil and reduced the formation of $\mathrm{NOx}, \mathrm{CO}$, and unburned hydrocarbons (HC) by $50 \%, 30 \%$, and $40 \%$, respectively [74]. Che Mat $\mathrm{S}$ et al. [12] have profoundly investigated the performance and emissions of compression ignition engines operating on various vegetable oil-alcohol blends. It is found that the addition of alcohols to blended biodiesel fuels is not only beneficial for reducing exhaust emissions [13,39], but also leads to an improvement in brake power (BP), an increase in BSFC, and an increase in BTE [44]. Alcohols have shown a critical reduction in NOx emissions in compression ignition engines [6]. It is noted that the reduction in NOx emission follows the fraction of alcohols (ethanol, methanol, and 
butanol) in biodiesel blends [22]. This is explained by the fact that the addition of alcohol improved the density, kinematic viscosity [44,47], surface tension, and oxygen content. Therefore, the spray quality was improved [44], the ignition delay period was reduced [6], and the combustion quality was improved [44].

Preheating is also used to reduce the viscosity of vegetable oils $[46,47,66,71]$. For example, heating thumba oil to $80-100{ }^{\circ} \mathrm{C}$ is enough to bring the oil's viscosity close to that of diesel fuel [71]. It leads to an increase in the combustion efficiency of pure oils and their blends [66,71], and provides a decrease in exhaust smoke opacity and emissions of $\mathrm{CO}$ and HC [71]. However, some increase in NOx emissions is possible [66]. By performing experimental studies in a large compression ignition diesel engine, Pipitone $\mathrm{E}$ and Costanza A [47] showed that preheating crude palm oil at $80^{\circ} \mathrm{C}$ significantly decreased its viscosity, which contributes to reducing the wear of parts, and eventually could reduce the formation of carbon deposits by $27 \%$ and increase the operating time of the engine by $30 \%$.

The addition of hydrogen to DF and biodiesel also has a positive effect on engine performance. Kanth S and Debbarma S [29] have shown that hydrogen enrichment increases the BTE of DF by $2.5 \%$ and the BTE of biodiesel by $1.6 \%$. This is attributed to improved combustion. As a result, for the blend of biodiesel and hydrogen, a decrease in $\mathrm{CO}$ emissions by 4-38\% [29] and an increase in $\mathrm{NO}_{\mathrm{X}}$ emissions [22] have been recorded. The addition of water to biodiesel also has a positive effect on engine performance. For example, when the fuel of a D-243 diesel engine was transferred from petroleum DF to an emulsion containing $90 \%$ rapeseed oil and $10 \%$ water, NOx emissions were reduced by $8-13 \%$, and exhaust smoke opacity was decreased by $26-42 \%$. At the same time, a reduction in emissions of unburned hydrocarbons $(\mathrm{HC})$ and an increase in $\mathrm{CO}$ emissions were recorded [53].

Most research has focused on the characteristics and performance of diesel engines fueled with biodiesel from rapeseed oil, palm oil, soybean oil, linseed oil, and mustard oil. Raman LA et al. [5] found that the BTE of an engine running on rapeseed oil biodiesel and its blends was lower than that for diesel fuel $[5,55]$. When pure biodiesel and its blends were used, there were higher BSFC and exhaust gas temperatures $[5,25,55]$. The maximum in-cylinder pressure, temperature, and heat release rate of blended biodiesel are lower than those of diesel fuel $[5,24]$. This contributes to reducing the formation of NOx emissions [24]. Similar results have been obtained in the study of other vegetable oils $[1,3,12,15,16,26,30,33,35,39,42,48,60,61]$.

With an increase in the percentage content of biodiesel in blended fuels, a decrease in engine torque $[15,24,25]$ and effective mean pressure $[24,42]$ and an increase in BSFC were noted $[1,32,33,39,48]$. This is due to the decreased calorific value $[1,24,25,42]$ and the higher viscosity for biodiesel $[12,15,24,64]$. At the same time, a higher density of biodiesel $[6,14,22,26,27,29-33,35-44,48-53,58,64]$ increases the amount of injected fuel $[24,39]$. This has an additional effect on the increase in BSFC [15] with an increase in the percentage content of biodiesel in blended fuel [24]. Thus, when diesel engines were fueled with biodiesel, the efficiency, as a rule, decreased. The power decreased by $3-10 \%$, depending on the share of diesel fuel replaced with vegetable oil in the blended biofuel. BSFC increased accordingly.

In general, the main goal of the abovementioned works was to replace petroleum DF with one or more renewable vegetable oils while reducing the toxicity of exhaust gases. Experimental results obtained in most cases showed reductions in emissions of harmful substances. This mainly refers to emissions of $\mathrm{CO}, \mathrm{HC}$, and particulate matter (smoke) $[1-3,15,24,27,33,36,42,50,52,60,66,72]$. Due to the use of biodiesel, reductions in CO emissions of $13 \%$ [53], 13.8\% [67], 5-15\% [61], 25\% [19], 28.6\% [30], 34.28\% [3], 35\% [45], $36 \%$ [72], 4-38\% [29], 50.47\% [60], 51\% [26], and 60.3\% [35] have been experimentally achieved. Moreover, $\mathrm{CO}$ emissions decrease as the concentration of biodiesel in blended fuels increases [45].

Reductions in HC emissions of 14\% [69], 14.3\% [30], 11-17\% [58], 17.5\% [3], 22\% [53], $30 \%$ [64], 31.8\% [19], 50\% [11], 55\% [26], and 85.9-86.7\% [35] have been experimentally 
achieved. However, when engine settings were retained the same as for DF operation, using blended fuel containing $20 \%$ of castor oil biodiesel or soybean oil biodiesel increased HC emissions by $16 \%$ and $18 \%$, respectively, compared to DF [57]. At the same time, higher levels of CO emissions were obtained. Based on this, Valente OS et al. [57] concluded that it is necessary to optimize the fuel injection system to reduce emissions of harmful substances into the atmosphere. Due to the use of biodiesel, significant reductions in exhaust smoke (emissions of particulate matter) of $11-16 \%$ [61], 15.8\% [48], 22\% [42], 25\% [72], 32.9\% [60], $26-42 \%$ [53], 45.6\% [13], and 51.0\% [3] have also been experimentally obtained.

As for NOx emissions, the use of various biodiesels and their blends with petroleum $\mathrm{DF}$ gives ambiguous and inconsistent results [22,55]. The influence of biodiesel on NOx emissions is still indefinite [41]. It depends not only on the feedstock, the percentage content in blends, and the transesterification method [24,41], but also on the design features of diesel engines. Nevertheless, in general, it is noted that NOx emissions increase with increasing the percentage content of biodiesel in blends [22,60] and increasing engine load [20,41,48,50,55]. Lešnik L and Biluš I [24] found that the different fuel compositions of biodiesel also affect the reduction in NOx emissions. By adding up to $5 \%$ rapeseed oil in DF, NOx emissions can either be reduced or maintained at levels similar to DF [54]. The combustion of diesel blends with less than $10 \%$ biodiesel results in lower NOx emissions [22,65,67]. Similar results were obtained with $5-20 \%$ biodiesel in blended fuel $[4,48,58,61]$.

The increase in NOx emissions with using various biodiesels and their blends with petroleum DF has been experimentally recorded in a large number of stud -ies $[3,5,15,16,19,27,29,30,33,35,36,42,45,63,66,72]$. The increase in NOx emissions on average ranged from $4.3-11.9 \%$ [16] to a maximum of almost 80.5\% [3]. Bari S and Hossain SN [26] experimentally found that due to the higher combustion temperature and oxygenated fuel, NOx emissions of palm oil biodiesel were, on average, $33 \%$ higher than those of petroleum DF. Waste frying oil blends also showed an increase in NOx emissions [41]. The high availability of oxygen in biodiesel, as a general rule, reduces the emission of $\mathrm{HC}, \mathrm{CO}$, and PM (exhaust smoke), while NOx emission increases significantly $[1,48,60]$. On the other hand, Lešnik $\mathrm{L}$ et al. showed that the use of biodiesel could contribute to a better oxidation process in the combustion chamber [25] and a decrease in in-cylinder temperature, pressure, and heat release rate, which reduces NOx emissions [24,25].

In order to reduce NOx emissions, the application of EGR has been investigated. Praveena $\mathrm{V}$ et al. [64] have experimentally found that the use of blended biodiesel along with EGR can reduce emissions of NOx and smoke. EGR of 5\% is optimal for reducing NOx emissions by $31.6 \%$ without any compromise in smoke emissions [64]. Manieniyan V et al. [31] achieved a reduction in NOx emissions of about $21.1 \%$ at $20 \%$ EGR.

In general, experimental studies of the performance and emission characteristics of engines operating on biodiesels were carried out with a wide range (from 5\% to 90\%) of volume fraction of various vegetable oils, wherein the studies were conducted for different engines: liquid $[7,17,18,46,52,53,61,62,65,67]$ and air $[3,6,26,33,37,38,50,66,72]$ cooling, single-cylinder $[3-6,13,16,18,26,33,35,37,38,43,44,46,49,51,60,64,66,71,72]$ and multicylinder $[7,15,17,52,53,58,61,62,65,67]$ with different displacement and fuel injection systems, including common rail [39], in a wide range of fuel injection pressures [5,15,22,37], at various loads $[2,6,11-13,15,16,20,22,25,29-32,35,37-44,46-53,55,57,58,60,62-64,72]$ and engine speeds from $1360 \mathrm{rpm}$ to $3600 \mathrm{rpm}[6,16,25,30,32,39,48,50,58]$. The results obtained often contradict each other. Therefore, significant differences in the materials used and experimental conditions do not allow the determination of the optimal percentage of vegetable oil addition and a quantitative comparison of the performance and emissions for a four-cylinder turbocharged liquid-cooled diesel engine with a displacement of 4-5 L.

The objective of the present work is to justify the possibility of using vegetable oils of different sources as a $10 \%$ additive in blended biofuel for diesel engines of agricultural machinery and commercial vehicles. The following vegetable oils have been considered as an ecological additive to petroleum DF: rapeseed oil, sunflower oil, soybean oil, corn oil, linseed oil, mustard oil, and camelina oil. All these vegetable oils were studied un- 
der the same conditions, despite the significant differences in chemical composition and physical parameters.

The choice of a $10 \%$ volume fraction of vegetable oils in blended biofuel is due to the fact that large additives of vegetable oils significantly increase the viscosity of blended biofuels and necessitate additional measures to ensure the efficient and reliable operation of a diesel engine with acceptable emission characteristics. Earlier, on the diesel engine D-245.12S, an optimal volume fraction of $10 \%$ was obtained for corn oil [67] and linseed oil, mustard oil, and camelina oil [61] blended diesel fuel. In addition, a mixture of $10 \%$ rapeseed oil biodiesel with diesel fuel had the highest power and torque values and the lowest BSFC and emissions of harmful substances [50]. It has also been obtained that the performance efficiency of the ternary blend ( $5 \%$ linseed biodiesel, $5 \%$ rubber seed biodiesel, $90 \%$ diesel fuel) is optimum compared to the other blends [18].

\section{Materials and Methods}

\subsection{Composition and Properties of Vegetable Oils}

The composition and properties of vegetable oils used for manufacturing biofuel are determined by the type of plants, cultivation conditions, and oilseed processing technologies. Saturated and unsaturated fatty acids constitute the basic components (up to 93-98\%) of the investigated vegetable oils. The composition of unrefined vegetable oils is listed in Table 1 [75].

Table 1. Fatty acid composition of unrefined vegetable oils.

\begin{tabular}{|c|c|c|c|c|c|c|}
\hline \multirow[b]{3}{*}{ Vegetable Oil } & \multicolumn{6}{|c|}{ Mass Fraction of Fatty Acids of Vegetable Oils, \% } \\
\hline & \multicolumn{3}{|c|}{ Saturated Fatty Acids } & \multicolumn{3}{|c|}{ Unsaturated Fatty Acids } \\
\hline & $\begin{array}{c}\text { Myristic } \\
\mathrm{C}_{14} \mathrm{H}_{28} \mathrm{O}_{2} \\
\text { or } \mathrm{C} 14: 0\end{array}$ & $\begin{array}{c}\text { Palmitic } \\
\mathrm{C}_{16} \mathrm{H}_{32} \mathrm{O}_{2} \\
\text { or } \mathrm{C} 16: 0\end{array}$ & $\begin{array}{c}\text { Stearic } \\
\mathrm{C}_{18} \mathrm{H}_{36} \mathrm{O}_{2} \\
\text { or } \mathrm{C} \mathrm{18:0}\end{array}$ & $\begin{array}{c}\text { Oleic } \\
\mathrm{C}_{18} \mathrm{H}_{34} \mathrm{O}_{2} \\
\text { or } \mathrm{C} \mathrm{18:1}\end{array}$ & $\begin{array}{c}\text { Linoleic } \\
\mathrm{C}_{18} \mathrm{H}_{32} \mathrm{O}_{2} \\
\text { or } \mathrm{C} \mathrm{18:2}\end{array}$ & $\begin{array}{c}\text { Linolenic } \\
\mathrm{C}_{18} \mathrm{H}_{30} \mathrm{O}_{2} \\
\text { or } \mathrm{C} \mathrm{18:3}\end{array}$ \\
\hline $\mathrm{RO}$ & $0 \ldots 0.2$ & $1.5 \ldots 6.0$ & $0.5 \ldots 3.1$ & $8.0 \ldots 60.0$ & $11.0 \ldots 23.0$ & $5.0 \ldots 13.0$ \\
\hline $\mathrm{SuO}$ & $0 \ldots 0.2$ & $5.6 \ldots 7.6$ & $2.7 \ldots 6.5$ & $14.0 \ldots 39.4$ & $18.3 \ldots 74.0$ & up to 0.3 \\
\hline SoO & $0 \ldots 0.2$ & $8.0 \ldots 13.5$ & $2.0 \ldots 5.4$ & $17.0 \ldots 30.0$ & $48.0 \ldots 59.0$ & $4.5 \ldots 11.0$ \\
\hline $\mathrm{CoO}$ & $0 \ldots 0.3$ & $8.6 \ldots 16.5$ & $0 \ldots 3.3$ & $20.0 \ldots 42.2$ & $34.0 \ldots 65.6$ & $0 \ldots 2.0$ \\
\hline $\mathrm{LO}$ & $5.4 \ldots 11.3$ & $2.5 \ldots 8.0$ & $0.4 \ldots 1.0$ & $13.0 \ldots 36.0$ & $8.3 \ldots 30.0$ & $30.0 \ldots 67.0$ \\
\hline $\mathrm{MO}$ & $0 \ldots 1.0$ & $0.5 \ldots 4.5$ & $0.5 \ldots 2.0$ & $8.0 \ldots 23.0$ & $10.0 \ldots 24.0$ & $6.0 \ldots 18.0$ \\
\hline $\mathrm{CaO}$ & $0 \ldots 0.2$ & $5.0 \ldots 7.0$ & $2.0 \ldots 2.5$ & $12.0 \ldots 20.0$ & $12.0 \ldots 20.0$ & $14.0 \ldots 22.0$ \\
\hline
\end{tabular}

Note: RO—rapeseed oil, SuO—sunflower oil, SoO—soybean oil, CoO—corn oil, LO—linseed oil, MO—mustard oil, CaO—camelina oil. After each fatty acid's name, its chemical formula and lipid numbers are given. In lipid numbers, the first number is the number of carbon atoms, and the second number is the number of double bonds in the molecule.

The main properties of petroleum DF of summer grade following GOST 305-2013 and vegetable oils with which the performance and emission characteristics of the diesel engine D-245.12S for agricultural machinery and commercial vehicles were studied are shown in Table 2 [53]. As can be seen, vegetable oils have a 10\% higher density and almost 20 times higher viscosity compared to petroleum DF. In addition, they are characterized by a lower calorific value (about 15\% lower) and a lower cetane number (nearly 20\% lower). One positive feature of vegetable oils is that they contain 25-27 times more oxygen than petroleum DF. However, due to the high content of fatty acids, they have a higher boiling point (almost 100 degrees higher) and are prone to thermal decomposition. All these differences have a significant impact on the atomization quality, evaporation rate, ignition delay, and combustion quality of biofuels from vegetable oils. 
Table 2. Properties of the investigated vegetable oils and petroleum DF.

\begin{tabular}{cccccccccc}
\hline \multirow{2}{*}{ Property } & \multicolumn{9}{c}{ Fuel Type } \\
\cline { 2 - 9 } & DF & RO & SuO & SO & CO & LO & MO & CaO \\
\hline Density at $20^{\circ} \mathrm{C}, \mathrm{kg} / \mathrm{m}^{3}$ & 830 & 916 & 923 & 923 & 921 & 912 & 920.0 & 910 \\
\hline Kinematic viscosity at $20^{\circ} \mathrm{C}, \mathrm{mm}^{2} / \mathrm{s}$ & 3.8 & 75.0 & 72.0 & 65.0 & 66.6 & 59.0 & 70.0 & 57.7 \\
\hline Lower calorific value, $\mathrm{MJ} / \mathrm{kg}$ & 42.5 & 37.3 & 37.4 & 37.3 & 37.1 & 37.6 & 37.2 & 37.5 \\
\hline Cetane number & 45 & 36 & 37 & 35 & 37 & 38 & 35 & 37 \\
\hline Theoretical air-fuel ratio & 14.31 & 12.52 & 12.36 & 12.38 & 12.38 & 12.62 & 12.44 & 12.52 \\
\hline
\end{tabular}

Note: the average values of the properties of petroleum DF have been given.

In addition, the positive qualities of biofuels from vegetable oils give hope for their use as an alternative fuel or a partial replacement of petroleum DF for diesel engines of agricultural machinery and commercial vehicles. From the perspective of future environmental requirements, the great advantages of vegetable oils are almost 100 times lower sulfur content and the complete absence of aromatic hydrocarbons, which are the source of carcinogens such as $\alpha$-benzopyrene.

Some physicochemical properties of the blended fuels of petroleum DF with different vegetable oils investigated in the study are presented in Table 3. It can be seen that the properties of the blended fuels containing $10 \%$ vegetable oils are slightly different from the properties of petroleum DF (Figure 1). For example, the density of the blended fuels is only $0.84-1.08 \%$ higher than that of petroleum DF (see Figure 1a). The lower calorific value of the blended fuels is only $1.18-1.41 \%$ lower than that of petroleum DF (see Figure 1b). Due to containing $90 \%$ petroleum DF in the blended fuels, their cetane number is lower than that of petroleum DF only by $1.56-2.22 \%$ (see Figure 1 c).

Table 3. Properties of investigated petroleum DF and its blends with vegetable oils.

\begin{tabular}{|c|c|c|c|c|c|c|c|c|}
\hline \multirow[b]{2}{*}{ Property } & \multicolumn{8}{|c|}{ Fuel Type } \\
\hline & DF & $\begin{array}{c}90 \% \text { DF + } \\
10 \% \text { RO }\end{array}$ & $\begin{array}{l}90 \% \mathrm{DF}+ \\
10 \% \mathrm{SuO}\end{array}$ & $\begin{array}{l}90 \% \text { DF + } \\
10 \% \text { SoO }\end{array}$ & $\begin{array}{l}90 \% \mathrm{DF}+ \\
10 \% \mathrm{CoO}\end{array}$ & $\begin{array}{c}90 \% \text { DF + } \\
10 \% \text { LO }\end{array}$ & $\begin{array}{l}90 \% \mathrm{DF}+ \\
10 \% \mathrm{MO}\end{array}$ & $\begin{array}{l}90 \% \mathrm{DF}+ \\
10 \% \mathrm{CaO}\end{array}$ \\
\hline Density at $20^{\circ} \mathrm{C}, \mathrm{kg} / \mathrm{m}^{3}$ & 830 & 839 & 839 & 838 & 839 & 837 & 839 & 838 \\
\hline Kinematic viscosity at $20^{\circ} \mathrm{C}, \mathrm{mm}^{2} / \mathrm{s}$ & 3.8 & 6.1 & 6.0 & 5.6 & 5.9 & 5.9 & 5.9 & 5.8 \\
\hline Lower calorific value, $\mathrm{MJ} / \mathrm{kg}$ & 42.5 & 41.9 & 41.9 & 42 & 42 & 41.9 & 41.9 & 42 \\
\hline Cetane number & 45 & 44.1 & 44.2 & 44 & 44.2 & 44.3 & 44 & 44.2 \\
\hline Theoretical air-fuel ratio & 14.31 & 14.12 & 14.16 & 14.13 & 14.11 & 14.16 & 14.11 & 14.13 \\
\hline \multicolumn{9}{|l|}{ Element mass content, \% } \\
\hline $\mathrm{C}$ & 87 & 86 & 86.1 & 85.9 & 86 & 86.1 & 86 & 86.1 \\
\hline $\mathrm{H}$ & 12.6 & 12.5 & 12.5 & 12.5 & 12.5 & 12.5 & 12.5 & 12.5 \\
\hline $\mathrm{O}$ & 0.4 & 1.5 & 1.4 & 1.6 & 1.5 & 1.4 & 1.5 & 1.4 \\
\hline
\end{tabular}

The exclusive physical parameter that significantly increases after adding $10 \%$ vegetable oils is the kinematic viscosity. At a temperature of $20{ }^{\circ} \mathrm{C}$, it increases by $1.47-1.84$ times (Figure 1e). When a diesel engine is operating, the fuel temperature is usually much higher, exceeding $100{ }^{\circ} \mathrm{C}$. Nevertheless, the increase in the kinematic viscosity of blended fuels will definitely affect the injection and spray processes.

The amount of air required for the combustion of $1 \mathrm{~kg}$ of blended fuel is also less than that for the combustion of petroleum DF, but only by $1.05-1.4 \%$ (Figure $1 \mathrm{~d}$ ). The addition of $10 \%$ vegetable oils that have a high oxygen content (Figure 2 ) into petroleum DF leads to an insignificant change in the mass composition. The carbon content decreases by $1.03-1.26 \%$, and the oxygen content, due to its low content in petroleum DF, on the contrary, increases 
by 3.5-4 times. However, this cannot significantly affect the air ratio, since the absolute content of oxygen in blended fuels increases only by $1.0-1.2 \%$.

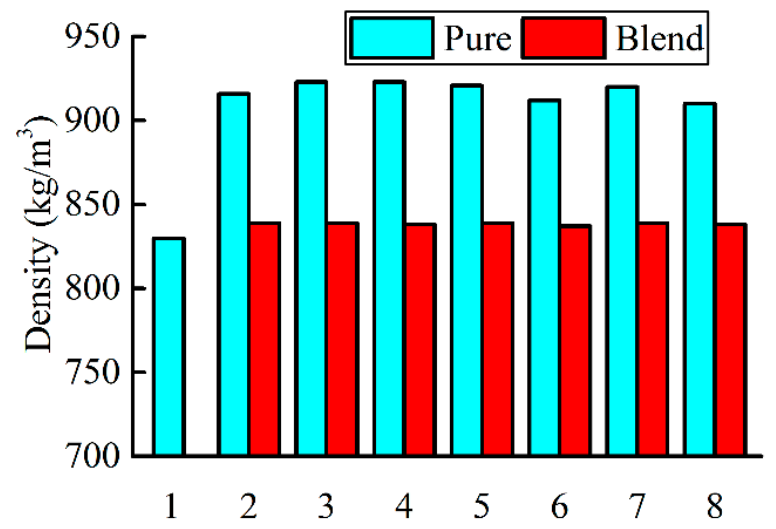

(a)

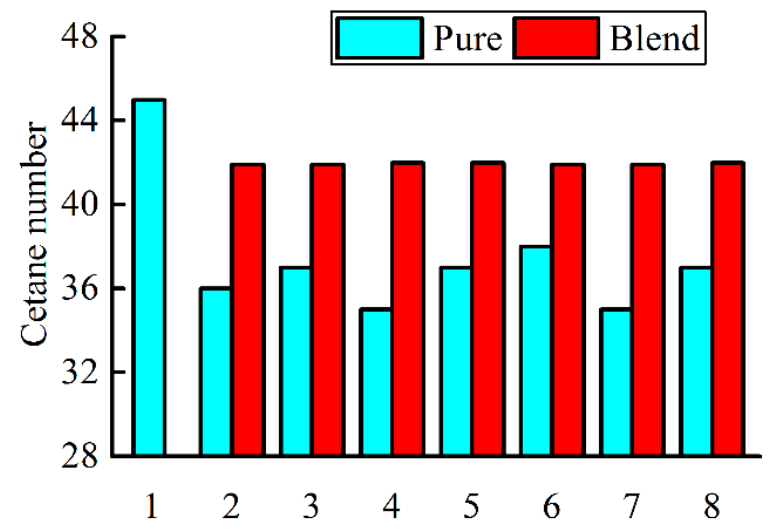

(c)

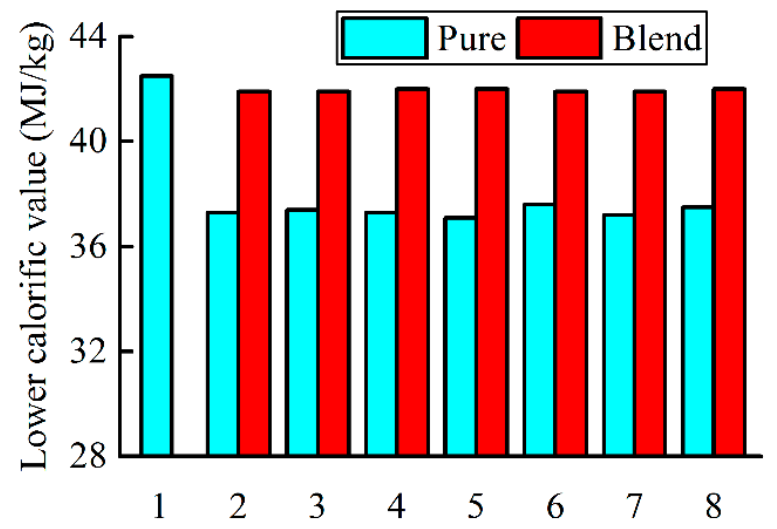

(b)

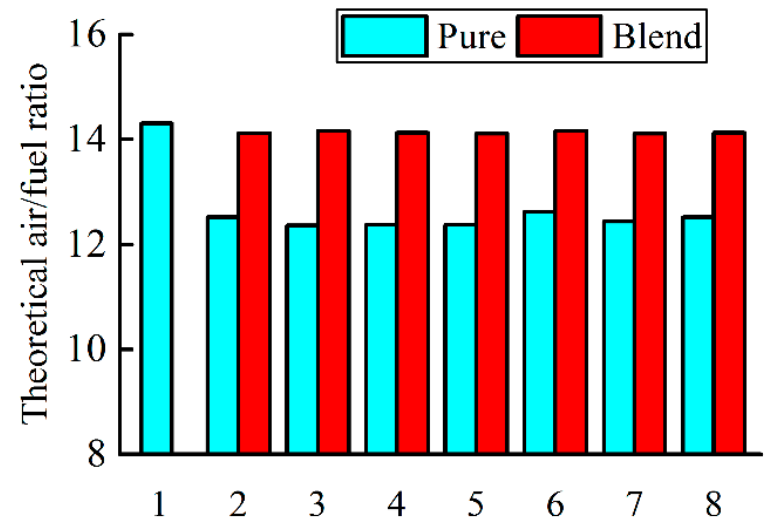

(d)

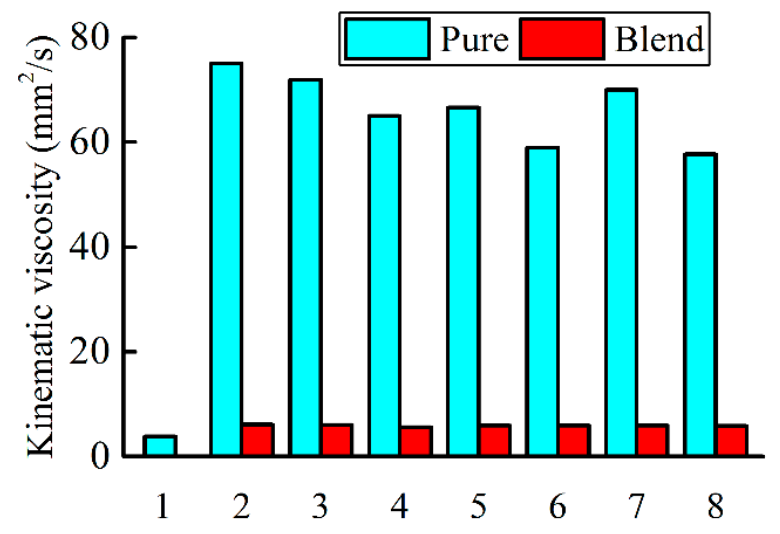

(e)

Figure 1. Properties of petroleum DF (1), investigated vegetable oils $(2-\mathrm{RO}, 3-\mathrm{SuO}, 4-\mathrm{SoO}, 5-\mathrm{CoO}, 6-\mathrm{LO}$, 7- $\mathrm{MO}, 8-\mathrm{CaO})$, and blended fuels with $10 \%$ vegetable oils: (a) — density; (b) - lower calorific value; (c) —cetane number; (d) —-theoretical air-fuel ratio; (e)—kinematic viscosity. 


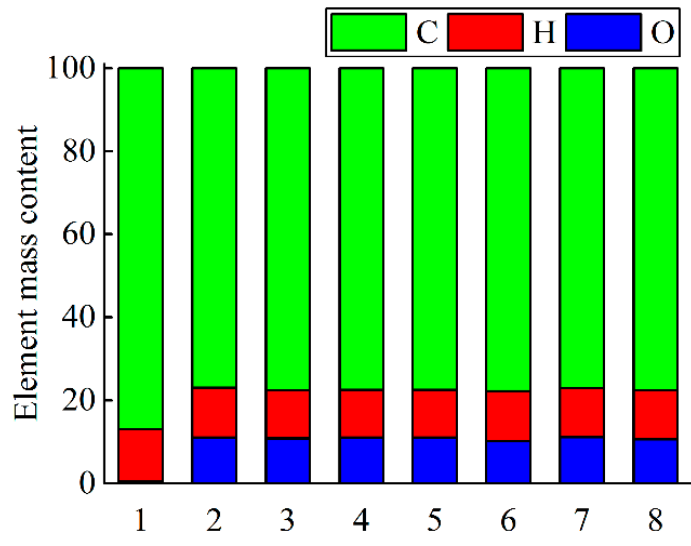

(a)

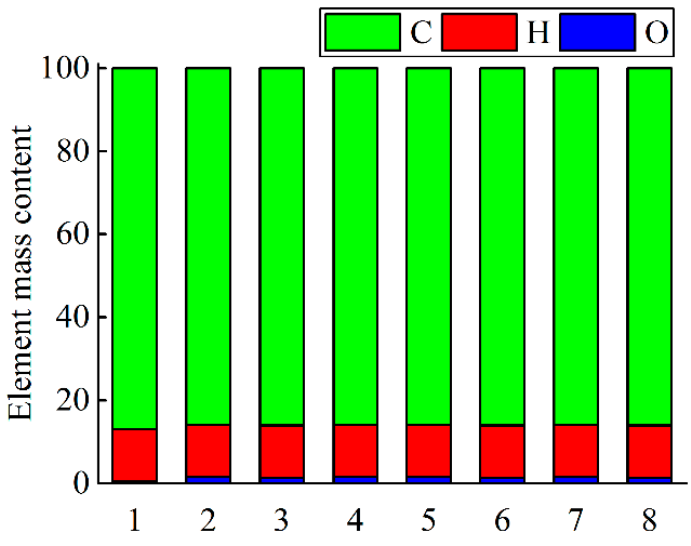

(b)

Figure 2. C, H, O mass content of pure petroleum DF and vegetable oils (a) and C, H, O mass content of the investigated blended fuels with adding $10 \%$ vegetable oil into DF (b): $1-\mathrm{DF}, 2-\mathrm{RO}, 3-\mathrm{SuO}, 4-\mathrm{SoO}, 5-\mathrm{CoO}, 6-\mathrm{LO}, 7-\mathrm{MO}, 8-\mathrm{CaO}$.

The analysis performed above indicates that there is no need to make adjustments to the diesel engine D-245.12S to investigate the performance of the diesel engine fueled with blends of $90 \%$ petroleum DF and $10 \%$ vegetable oils. This is consistent with the results of other studies using biodiesels without significant changes for the existing transport infrastructure $[4,5,15-18,55]$.

\subsection{Experimental Setup and Test Procedure}

Experimental investigations of the operation characteristics of a diesel engine fueled with blends of petroleum DF with $10 \%$ different vegetable oils have been carried out on the diesel engine D-245.12S. This engine is widely used as a power source for agricultural machinery and commercial vehicles. The main parameters of this diesel engine are given in Table 4.

Table 4. Structure and operational parameters of the diesel engine D-245.12S.

\begin{tabular}{cc}
\hline Parameters & Value \\
\hline Engine type & Four-stroke, in-line, diesel \\
\hline Number of cylinders & 110 \\
\hline Cylinder diameter $D, \mathrm{~mm}$ & 125 \\
\hline Piston stroke $S, \mathrm{~mm}$ & 4.32 \\
\hline Total cylinder capacity $i V_{\mathrm{h}, \mathrm{L}}$ & 15.1 \\
\hline Compression ratio $\varepsilon$ & CC of type CNIDI (Central Diesel Engine Research Institute), \\
\hline Combustion chamber $(\mathrm{CC})$ type, \\
air-fuel mixing method
\end{tabular}


Experimental investigations of the diesel engine D-245.12S were carried out on a test bench equipped with all the necessary equipment for recording the speed, torque, power, fuel and air consumption, temperatures, and pressures in engine systems, as well as the content of regulated harmful substances in exhaust gases. The basis of the test bench is a balancing dynamometer DS-1036-4U (TES Vsetin, Vsetin, Czech Republic) for measuring the rotational speed, torque, and power of the diesel engine. The contents of harmful substances in exhaust gases were measured with an SAE-7532 gas analyzer (Yanaco, Kyoto, Japan) and an MK-3 smoke meter (Hartridge, Buckingham, UK). The main specifics of the equipment used are given in Table 5.

Table 5. Main measurement parameters.

\begin{tabular}{cccc}
\hline Measured Parameter & Measuring Range & Accuracy & Uncertainty \\
\hline Engine speed & $0-5000 \mathrm{rpm}$ & $\pm 5 \mathrm{rpm}$ & $\pm 0.1 \%$ \\
\hline Torque moment & $0-500 \mathrm{Nm}$ & $\pm 5 \mathrm{Nm}$ & $\pm 1 \%$ \\
\hline Engine power & $0-100 \mathrm{~kW}$ & $\pm 0.5 \mathrm{~kW}$ & $\pm 1 \%$ \\
\hline Fuel consumption & $0-40 \mathrm{~kg} / \mathrm{h}$ & $\pm 0.1 \mathrm{~kg} / \mathrm{h}$ & $\pm 0.25 \%$ \\
\hline Air consumption & $0-1000 \mathrm{~kg} / \mathrm{h}$ & $\pm 10 \mathrm{~kg} / \mathrm{h}$ & $\pm 1 \%$ \\
\hline NOx & $0-4000 \mathrm{ppm}$ & $<1000 \mathrm{ppm}: \pm 10 \mathrm{ppm}$ & $\geq 1000 \mathrm{ppm}: \pm 5 \%$ \\
\hline CO & $0-5 \mathrm{vol} \%$ & $<1 \mathrm{vol} \%: \pm 0.03 \mathrm{vol} \%$ & $\geq 1 \mathrm{vol} \%: \pm 3 \mathrm{vol} \%$ \\
\hline HC & $0-2000 \mathrm{ppm}$ & $<200 \mathrm{ppm}: \pm 10 \mathrm{ppm}$ & $\geq 200 \mathrm{ppm:} \pm 5 \%$ \\
\hline Exhaust gas smoke & $0-100 \%$ & $\pm 1 \%$ full-scale reading & - \\
\hline
\end{tabular}

The diesel engine D-245.12S was tested in the operating conditions of the 13-mode test cycle of ECE R49 of UNECE Regulation No. 49 (Figure 3). The fuel injection advance angle $\left(\theta=13^{\circ} \mathrm{CA}\right)$ and the limiting position of the fuel injection pump control rack remained unchanged. The most loaded modes were modes No. 6 and 8 with a maximum torque and operating time of $25 \%$ and $10 \%$, respectively. During the long-term tests, petroleum DF from different supplies was used. Therefore, the experimental results of petroleum DF in Tables 6-9 are somewhat different from each other.

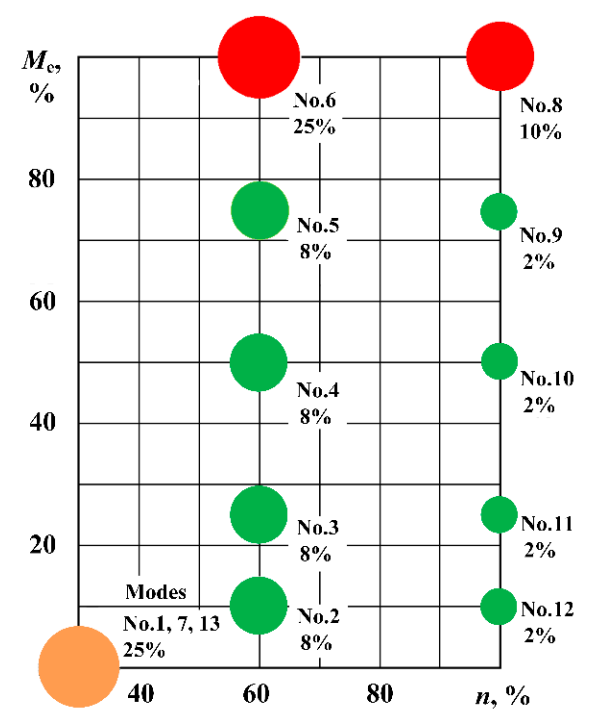

Figure 3. The European 13-mode steady-state diesel engine test cycle (ECE R49) used for emission testing of vehicle engines. Signs ' $\mathrm{No}^{\prime}$ and '\%' denote the sequential number of the operating mode and its time-share, respectively. The signs ' $M_{\mathcal{e}}$ ' and ' $n$ ' denote the values of the brake torque and speed in $\%$ relative to the maximum values. 
Table 6. The main parameters of the diesel engine running on petroleum DF and its blends with the investigated vegetable oils in the maximum power mode $\left(N_{\max }\right)$ and in the maximum torque mode $\left(M_{\max }\right)$.

\begin{tabular}{|c|c|c|c|c|c|c|c|c|c|c|}
\hline \multirow[b]{2}{*}{ Fuel Type } & \multicolumn{10}{|c|}{ Engine Indicators } \\
\hline & $\begin{array}{c}N e \text { in } \\
N_{\max } \\
\mathbf{k W}\end{array}$ & $\begin{array}{c}\text { Ne in } \\
M_{\max } \\
\text { kW }\end{array}$ & $\begin{array}{l}n \text { in } \\
N_{\max } \\
\text { rpm }\end{array}$ & $\begin{array}{c}n \text { in } \\
M_{\max } \\
\text { rpm }\end{array}$ & $\begin{array}{c}M_{\mathrm{e}} \text { in } \\
N_{\max } \\
\mathrm{N} \cdot \mathrm{m}\end{array}$ & $\begin{array}{c}M_{\mathrm{e}} \text { in } \\
M_{\max } \\
\mathrm{N} \cdot \mathrm{m}\end{array}$ & $\begin{array}{c}G_{\mathrm{f}} \text { in } \\
N_{\max } \\
\mathrm{kg} / \mathrm{h}\end{array}$ & $\begin{array}{c}G_{\mathrm{f}} \text { in } \\
M_{\max } \\
\mathrm{kg} / \mathrm{h}\end{array}$ & $\begin{array}{c}g_{e} \text { in } \\
N_{\max } \\
\mathrm{g} /(\mathrm{kW} \cdot \mathrm{h})\end{array}$ & $\begin{array}{c}g_{e} \text { in } \\
M_{\max } \\
\mathrm{g} /(\mathrm{kW} \cdot \mathrm{h})\end{array}$ \\
\hline Petroleum DF & 75.54 & 53.59 & 2397 & 1501 & 301 & 341 & 18.81 & 12.1 & 249 & 225.8 \\
\hline $90 \% \mathrm{DF}+10 \% \mathrm{RO}$ & 76.90 & 55.38 & 2408 & 1520 & 305 & 348 & 19.38 & 12.67 & 252 & 228.8 \\
\hline Petroleum DF & 79.82 & 61.64 & 2405 & 1600 & 317 & 368 & 19.7 & 13.72 & 246.8 & 222.6 \\
\hline $90 \% \mathrm{DF}+10 \% \mathrm{SuO}$ & 79.43 & 61.57 & 2400 & 1602 & 316 & 367 & 19.96 & 13.97 & 251.3 & 226.9 \\
\hline Petroleum DF & 80.92 & 57.91 & 2400 & 1503 & 322 & 368 & 20.1 & 13.1 & 248.4 & 226.2 \\
\hline $90 \% \mathrm{DF}+10 \% \mathrm{SoO}$ & 80.44 & 56.79 & 2401 & 1502 & 320 & 361 & 20.4 & 13.01 & 253.6 & 229.1 \\
\hline Petroleum DF & 78.08 & 56.20 & 2398 & 1499 & 311 & 358 & 19.31 & 12.56 & 247.3 & 223.5 \\
\hline $90 \% \mathrm{DF}+10 \% \mathrm{CoO}$ & 76.89 & 55.74 & 2400 & 1500 & 306 & 355 & 19.36 & 12.52 & 251.8 & 224.6 \\
\hline Petroleum DF & 80.92 & 57.91 & 2400 & 1503 & 322 & 368 & 20.1 & 13.1 & 248.4 & 226.2 \\
\hline $90 \% \mathrm{DF}+10 \% \mathrm{LO}$ & 80.29 & 57.71 & 2404 & 1502 & 319 & 367 & 20.24 & 13.28 & 252.1 & 230.1 \\
\hline Petroleum DF & 80.58 & 57.47 & 2397 & 1508 & 321 & 364 & 20 & 13 & 248.2 & 226.2 \\
\hline $90 \% \mathrm{DF}+10 \% \mathrm{MO}$ & 79.91 & 57.01 & 2400 & 1500 & 318 & 363 & 20.25 & 13.22 & 253.4 & 231.9 \\
\hline Petroleum DF & 80.58 & 57.47 & 2397 & 1508 & 321 & 364 & 20 & 13 & 248.2 & 226.2 \\
\hline $90 \% \mathrm{DF}+10 \% \mathrm{CaO}$ & 79.77 & 56.38 & 2403 & 1504 & 317 & 358 & 20.23 & 13.3 & 253.6 & 235.9 \\
\hline
\end{tabular}

Table 7. NOx emissions and exhaust smoke opacity of the diesel engine D-245.12.S fueled with vegetable oil-blended DF in the maximum power mode $\left(N_{\max }\right)$ and in the maximum torque mode $\left(M_{\max }\right)$.

\begin{tabular}{|c|c|c|c|c|c|c|c|c|}
\hline \multirow[b]{2}{*}{ Fuel Type } & \multicolumn{8}{|c|}{ Engine Indicators } \\
\hline & $\begin{array}{l}C_{\mathrm{NOx}} \text { in } N_{\max } \\
p p m / \mathrm{g} / \mathrm{kW} \cdot \mathrm{h}\end{array}$ & $\Delta C_{\mathrm{NOx}}, \%$ & $\begin{array}{c}C_{\mathrm{NOx}} \text { in } M_{\max } \\
p p m / \mathrm{g} / \mathrm{kW} \cdot \mathrm{h}\end{array}$ & $\Delta C_{\mathrm{NOx}}, \%$ & $\begin{array}{c}K_{\mathrm{X}} \text { in } N_{\max } \\
\%(\mathrm{H} .)\end{array}$ & $\Delta K_{X}, \%$ & $\begin{array}{c}K_{\mathrm{X}} \text { in } M_{\max } \\
\% \text { (H.) }\end{array}$ & $\Delta K_{X}, \%$ \\
\hline \multicolumn{9}{|c|}{ Petroleum DF, RO-blended DF } \\
\hline Petroleum DF & $675 / 8.27$ & - & $800 / 5.81$ & - & 11.0 & - & 25.0 & - \\
\hline $90 \% \mathrm{DF}+10 \% \mathrm{RO}$ & $660 / 8.05$ & $-2.2 /-2.6$ & $785 / 5.67$ & $-1.9 /-2.4$ & 9.5 & -13.6 & 20.5 & -18.0 \\
\hline \multicolumn{9}{|c|}{ Petroleum DF, SuO-blended DF } \\
\hline Petroleum DF & $605 / 7.40$ & - & $680 / 5.20$ & - & 14,5 & - & 20.0 & - \\
\hline $90 \% \mathrm{DF}+10 \% \mathrm{SuO}$ & $580 / 7.10$ & $-4.1 /-4.0$ & $675 / 5.17$ & $-0.7 /-0.6$ & 12,0 & -17.2 & 15.0 & -25.0 \\
\hline \multicolumn{9}{|c|}{ Petroleum DF, SoO-blended DF } \\
\hline Petroleum DF & $605 / 7.80$ & - & $700 / 5.48$ & - & 16.0 & - & 43.0 & - \\
\hline $90 \% \mathrm{DF}+10 \% \mathrm{SoO}$ & $560 / 7.23$ & $-7.4 /-7.3$ & $650 / 5.11$ & $-7.1 /-6.9$ & 10.0 & -37.5 & 31.0 & -27.9 \\
\hline \multicolumn{9}{|c|}{ Petroleum DF, CoO-blended DF } \\
\hline Petroleum DF & $600 / 7.37$ & - & $650 / 5.44$ & - & 18.0 & - & 40.0 & - \\
\hline $90 \% \mathrm{DF}+10 \% \mathrm{CoO}$ & $550 / 6.77$ & $-8.3 /-8.1$ & $620 / 5.11$ & $-4.6 /-4.4$ & 14.0 & -22.2 & 37.0 & -7.5 \\
\hline \multicolumn{9}{|c|}{ Petroleum DF, LO-blended DF } \\
\hline Petroleum DF & $605 / 7.38$ & - & $700 / 5.87$ & - & 16.0 & - & 43.0 & - \\
\hline $90 \% \mathrm{DF}+10 \% \mathrm{LO}$ & $570 / 6.96$ & $-5.8 /-5.7$ & $690 / 5.80$ & $-1.4 /-1.2$ & 11.0 & -31.3 & 36.0 & -16.3 \\
\hline \multicolumn{9}{|c|}{ Petroleum DF, MO-blended DF } \\
\hline Petroleum DF & $550 / 6.30$ & - & $640 / 5.01$ & - & 17.0 & - & 42.0 & - \\
\hline $90 \% \mathrm{DF}+10 \% \mathrm{MO}$ & $545 / 6.25$ & $-0.9 /-0.8$ & $625 / 4.90$ & $-2.3 /-2.2$ & 12.0 & -29.4 & 36.0 & -14.3 \\
\hline \multicolumn{9}{|c|}{ Petroleum DF, CaO-blended DF } \\
\hline Petroleum DF & $550 / 6.30$ & - & $640 / 5.01$ & - & 17.0 & - & 42.0 & - \\
\hline $90 \% \mathrm{DF}+10 \% \mathrm{CaO}$ & $525 / 6.03$ & $-4.5 /-4.3$ & $620 / 4.86$ & $-3.1 /-3.0$ & 15 & -11.8 & 36.0 & -14.3 \\
\hline
\end{tabular}


Table 8. Emissions of CO and HC of the diesel engine D-245.12.S fueled with vegetable oil-blended DF in the maximum power mode $\left(N_{\max }\right)$ and in the maximum torque mode $\left(M_{\max }\right)$.

\begin{tabular}{|c|c|c|c|c|c|c|c|c|}
\hline \multirow[b]{2}{*}{ Fuel Type } & \multicolumn{8}{|c|}{ Engine Indicators } \\
\hline & $\begin{array}{l}C_{\mathrm{CO}} \text { in } N_{\max } \\
p p m / \mathrm{g} / \mathrm{kW} \cdot \mathbf{h}\end{array}$ & $\begin{array}{l}\Delta C_{\mathrm{CO}} \text { in } \\
N_{\max }, \%\end{array}$ & $\begin{array}{l}C_{\mathrm{CO} \text { in } M_{\max }} \\
p p m / \mathrm{g} / \mathrm{kW} \cdot \mathbf{h}\end{array}$ & $\begin{array}{l}\Delta C_{\mathrm{CO}} \text { in } \\
M_{\max } \%\end{array}$ & $\begin{array}{l}C_{\mathrm{HC}} \text { in } N_{\max } \\
p p m / \mathrm{g} / \mathrm{kW} \cdot \mathrm{h}\end{array}$ & $\begin{array}{l}\Delta C_{\mathrm{HC}} \text { in } \\
N_{\max }, \%\end{array}$ & $\begin{array}{l}C_{\mathrm{HC}} \text { in } M_{\max } \\
p p m / \mathrm{g} / \mathrm{kW} \cdot \mathrm{h}\end{array}$ & $\begin{array}{l}\Delta C_{\mathrm{HC}} \text { in } \\
M_{\max }, \%\end{array}$ \\
\hline \multicolumn{9}{|c|}{ Petroleum DF, RO-blended DF } \\
\hline Petroleum DF & $210 / 1.60$ & - & $330 / 3.17$ & - & $150 / 1.07$ & - & $170 / 0.79$ & - \\
\hline $90 \% \mathrm{DF}+10 \% \mathrm{RO}$ & $200 / 1.52$ & $-4.8 /-5.0$ & $305 / 2.92$ & $-7.6 / 7.9$ & $120 / 0.85$ & $-20.0 /-20.5$ & $130 / 0.60$ & $-23.5 /-24.0$ \\
\hline \multicolumn{9}{|c|}{ Petroleum DF, SuO-blended DF } \\
\hline Petroleum DF & $165 / 1.02$ & - & $315 / 2.01$ & - & $105 / 0.41$ & - & $82 / 0.32$ & - \\
\hline $90 \% \mathrm{DF}+10 \% \mathrm{SuO}$ & $160 / 0.99$ & $-3.0 /-2.9$ & $270 / 1.73$ & $-14.3 /-13.9$ & $95 / 0.37$ & $-9.5 /-9.7$ & $73 / 0.29$ & $-11.0 /-9.4$ \\
\hline \multicolumn{9}{|c|}{ Petroleum DF, SoO-blended DF } \\
\hline Petroleum DF & $102 / 0.81$ & - & $330 / 1.59$ & - & $108 / 0.56$ & - & $170 / 0.42$ & - \\
\hline $90 \% \mathrm{DF}+10 \% \mathrm{SoO}$ & $96 / 0.76$ & $-5.9 /-6.2$ & $285 / 1.38$ & $-13.6 /-13.2$ & $99 / 0.52$ & $-8.3 /-7.1$ & $150 / 0.37$ & $-11.8 /-11.9$ \\
\hline \multicolumn{9}{|c|}{ Petroleum DF, CoO-blended DF } \\
\hline Petroleum DF & $255 / 1.79$ & - & $470 / 2.29$ & - & $163 / 0.68$ & - & $201 / 0.60$ & - \\
\hline $90 \% \mathrm{DF}+10 \% \mathrm{CoO}$ & $210 / 1.48$ & $-17.6 /-17.3$ & $450 / 2.20$ & $-4.3 /-3.9$ & $120 / 0.52$ & $-24.4 /-23.5$ & $145 / 0.45$ & $-27.9 /-25.0$ \\
\hline \multicolumn{9}{|c|}{ Petroleum DF, LO-blended DF } \\
\hline Petroleum DF & $102 / 0.69$ & - & $330 / 1.56$ & - & $108 / 0.39$ & - & $170 / 0.44$ & - \\
\hline $90 \% \mathrm{DF}+10 \% \mathrm{LO}$ & $85 / 0.58$ & $-16.7 /-15.9$ & $280 / 1.32$ & $-15.2 /-15.4$ & $83 / 0.30$ & $-23.1 /-23.1$ & $130 / 0.34$ & $-23.5 /-22.7$ \\
\hline \multicolumn{9}{|c|}{ Petroleum DF, MO-blended DF } \\
\hline Petroleum DF & $100 / 0.71$ & - & $300 / 1.47$ & - & $76 / 0.28$ & - & $130 / 0.34$ & - \\
\hline $90 \% \mathrm{DF}+10 \% \mathrm{MO}$ & $91 / 0.65$ & $-9.0 /-8.5$ & $275 / 1.35$ & $-8.3 /-8.2$ & $61 / 0.23$ & $-19.7 /-17.9$ & $105 / 0.28$ & $-19.2 /-17.6$ \\
\hline \multicolumn{9}{|c|}{ Petroleum DF, CaO-blended DF } \\
\hline Petroleum DF & $100 / 0.71$ & - & $300 / 1.47$ & - & $76 / 0.28$ & - & $130 / 0.34$ & - \\
\hline $90 \% \mathrm{DF}+10 \% \mathrm{CaO}$ & $80 / 0.57$ & $-20.0 /-19.7$ & $270 / 1.33$ & $-10.0 /-9.5$ & $60 / 0.23$ & $-21.1 /-17.8$ & $116 / 0.31$ & $-10.8 /-8.8$ \\
\hline
\end{tabular}

Table 9. Integral (average) parameters of the diesel engine D-245.12S running on petroleum DF and its blends with the investigated vegetable oils in the European 13-mode steady-state test cycle (ECE R49).

\begin{tabular}{|c|c|c|c|c|}
\hline \multirow{2}{*}{ Fuel Type } & \multicolumn{4}{|c|}{ Engine Indicators } \\
\hline & $g_{e}$ ave, $\mathrm{g} /(\mathrm{kW} \cdot \mathrm{h})$ & $e_{\mathrm{NOx}}, \mathrm{g} /(\mathrm{kW} \cdot \mathrm{h})$ & $e_{\mathrm{CO}}, \mathrm{g} /(\mathrm{kW} \cdot \mathrm{h})$ & $e_{\mathrm{HC}}, \mathrm{g} /(\mathrm{kW} \cdot \mathrm{h})$ \\
\hline \multicolumn{5}{|c|}{ Petroleum DF, RO-blended DF } \\
\hline Petroleum DF & 247.20 & 7.442 & 3.482 & 1.519 \\
\hline $90 \% \mathrm{DF}+10 \% \mathrm{RO}$ & 250.79 & 7.300 & 3.332 & 1.202 \\
\hline \multicolumn{5}{|c|}{ Petroleum DF, SuO-blended DF } \\
\hline Petroleum DF & 230.52 & 6.630 & 2.210 & 0.580 \\
\hline $90 \% \mathrm{DF}+10 \% \mathrm{SuO}$ & 246.09 & 6.649 & 2.091 & 0.530 \\
\hline \multicolumn{5}{|c|}{ Petroleum DF, SoO-blended DF } \\
\hline Petroleum DF & 247.97 & 7.018 & 1.723 & 0.788 \\
\hline $90 \% \mathrm{DF}+10 \% \mathrm{SoO}$ & 251.42 & 5.896 & 1.548 & 0.762 \\
\hline \multicolumn{5}{|c|}{ Petroleum DF, CoO-blended DF } \\
\hline Petroleum DF & 244.32 & 6.549 & 3.277 & 1.104 \\
\hline $90 \% \mathrm{DF}+10 \% \mathrm{CoO}$ & 248.22 & 6.337 & 2.825 & 0.773 \\
\hline \multicolumn{5}{|c|}{ Petroleum DF, LO-blended DF } \\
\hline Petroleum DF & 247.97 & 7.018 & 1.723 & 0.788 \\
\hline $90 \% \mathrm{DF}+10 \% \mathrm{LO}$ & 252.26 & 6.441 & 1.511 & 0.664 \\
\hline
\end{tabular}


Table 9. Cont.

\begin{tabular}{|c|c|c|c|c|}
\hline \multirow{2}{*}{ Fuel Type } & \multicolumn{4}{|c|}{ Engine Indicators } \\
\hline & $g_{e}$ ave, $\mathrm{g} /(\mathrm{kW} \cdot \mathbf{h})$ & $e_{\text {NOx }}, \mathrm{g} /(\mathrm{kW} \cdot \mathrm{h})$ & $e_{\mathrm{CO}}, \mathrm{g} /(\mathrm{kW} \cdot \mathrm{h})$ & $e_{\mathrm{HC}}, \mathrm{g} /(\mathrm{kW} \cdot \mathrm{h})$ \\
\hline \multicolumn{5}{|c|}{ Petroleum DF, MO-blended DF } \\
\hline Petroleum DF & 244.63 & 5.911 & 2.184 & 0.675 \\
\hline $90 \% \mathrm{DF}+10 \% \mathrm{MO}$ & 251.08 & 5.689 & 2.068 & 0.561 \\
\hline \multicolumn{5}{|c|}{ Petroleum DF, CaO-blended DF } \\
\hline Petroleum DF & 244.63 & 5.911 & 2.184 & 0.675 \\
\hline $90 \% \mathrm{DF}+10 \% \mathrm{CaO}$ & 255.57 & 5.341 & 1.853 & 0.585 \\
\hline
\end{tabular}

In the operating modes of maximum power and maximum torque, the main power and economic indicators of the diesel engine and the content of regulated harmful substances (nitrogen oxides (NOx), solid particles, carbon monoxide (CO), unburned hydrocarbons $(\mathrm{HC})$ ) were recorded. Similar measurements were carried out during tests over the entire 13-mode cycle for blended fuels of petroleum DF with $10 \%$ vegetable oils.

Given the insignificant differences in physicochemical properties between blended fuels of petroleum DF with 10\% vegetable oils and petroleum DF (Table 3 and Figures 1 and 2), all tests of the diesel engine D-245.12S were conducted under the identical control parameters of fuel equipment.

\subsection{Methodology of Processing Experimental Results}

The brake-specific fuel consumption (BSFC) $g_{e}$ has been calculated from the experimentally obtained values of the hourly consumption of blended fuels $G_{f}$ according to the known formula:

$$
\mathrm{g}_{e}=1000 \cdot \mathrm{G}_{\mathrm{f}} / N_{e},
$$

The operational consumption of the blended fuel over the 13-mode test cycle was estimated with the average brake-specific fuel consumption (ABSFC) $g_{e_{-} \text {ave, which was }}$ determined by the following formula:

$$
\mathrm{g}_{\text {e_ave }}=\sum_{i=1}^{13} \mathrm{G}_{\mathrm{f}, i} \cdot K_{i} / \sum_{i=1}^{13} N_{e, i} \cdot K_{i} \text {, }
$$

where $G_{f, i}$ and $N_{e, i}$ are the hourly fuel consumption and brake power, respectively, in the $i$-th operating mode; $K_{i}$ is the time-share of the $i$-th operating mode.

These parameters of the diesel engine have been calculated in accordance with the formulas given above.

The emission characteristics of the diesel engine were evaluated based on the concentrations of $\mathrm{NOx}, \mathrm{CO}, \mathrm{HC}$, and solid particles in exhaust gases $\left(C_{\mathrm{NO}}, \mathrm{C}_{\mathrm{CO}}, \mathrm{C}_{\mathrm{HC}}, K_{\mathrm{x}}\right)$, which have been experimentally obtained in each operating mode of the 13-mode test cycle for all blended fuels of petroleum DF with $10 \%$ vegetable oils.

Based on the above measured and calculated values and with taking into account the operation time (duration) of each operating mode, the hourly mass emissions of $\mathrm{NOx}, \mathrm{CO}$, and $\mathrm{HC}\left(E_{\mathrm{NOx}}, E_{\mathrm{CO}}\right.$, and $\left.E_{\mathrm{HC}}\right)$ were determined. The total emissions of each substance (summed with the taken account of the coefficient $K_{i}$ ) were divided by the average brake power of the diesel engine over the test cycle $\left(\Sigma\left(N_{e i} \cdot K_{i}\right)\right)$ to calculate the integral brakespecific emissions of NOx, CO, and HC (IBSNOx, IBSCO, and IBSHC) over the whole 13 -mode test cycle (denoted by $e_{\mathrm{NO}}, e_{\mathrm{CO}}$, and $e_{\mathrm{CHx}}$, respectively) in accordance with the following formulas:

$$
e_{\mathrm{NOx}}=\sum_{i=1}^{13} E_{\mathrm{NOx}, i} \cdot K_{i} / \sum_{i=1}^{13} N_{e, i} \cdot K_{i} \text {; }
$$




$$
\begin{aligned}
& e_{\mathrm{CO}}=\sum_{i=1}^{13} E_{\mathrm{CO}, i} \cdot K_{i} / \sum_{i=1}^{13} N_{e, i} \cdot K_{i} ; \\
& e_{\mathrm{HC}}=\sum_{i=1}^{13} E_{H C, i} \cdot K_{i} / \sum_{i=1}^{13} N_{e, i} \cdot K_{i} .
\end{aligned}
$$

\section{Results and Discussion}

3.1. Test Results of the Diesel Engine D-245.12S in the Operating Modes of Maximum Power and Maximum Torque

The test results on the main technical and economic indicators of the diesel engine D-245.12S in the operating modes of maximum power and maximum torque (modes No. 6 and No. 8 in Figure 3) are given in Table 6 and Figure 4. As shown in Figure 4a,b, it is evident that the use of a $10 \%$ vegetable oil additive results in a decrease in brake power and brake torque for almost all blended fuels under unchanged fuel equipment controls. Generally, this decrease does not exceed $1.5 \%$ with the addition of different vegetable oils. The only exception was obtained when the diesel engine was fueled with the rapeseed oil-blended fuel. In these experiments, the brake torque was increased by $1.33 \%$ in the maximum power mode and $2.05 \%$ in the maximum torque mode. These data are consistent with the results reported in the work of Reza Miri SM et al. [50], where the highest power and torque values were obtained for blended petroleum DF with $10 \%$ non-edible rapeseed biodiesel at engine speeds of 2600 and 1800 and under two loading states (75\% and 100\%).

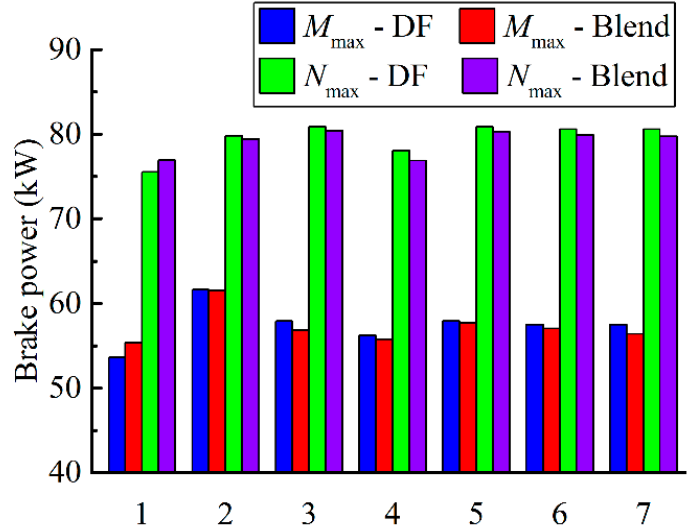

(a)

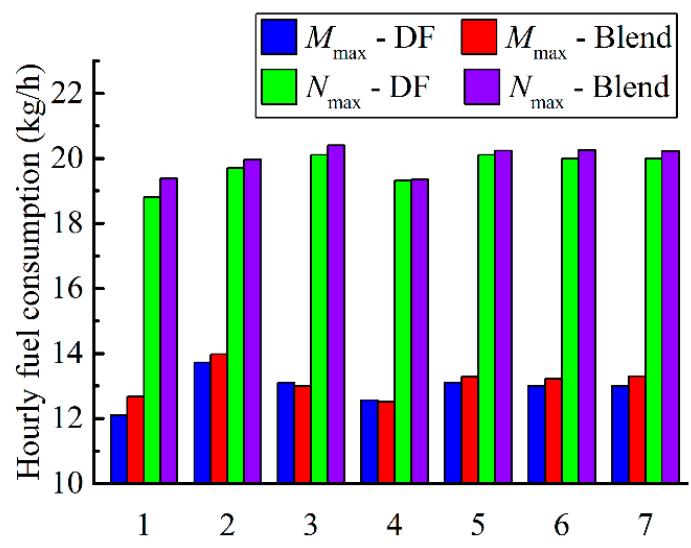

(c)

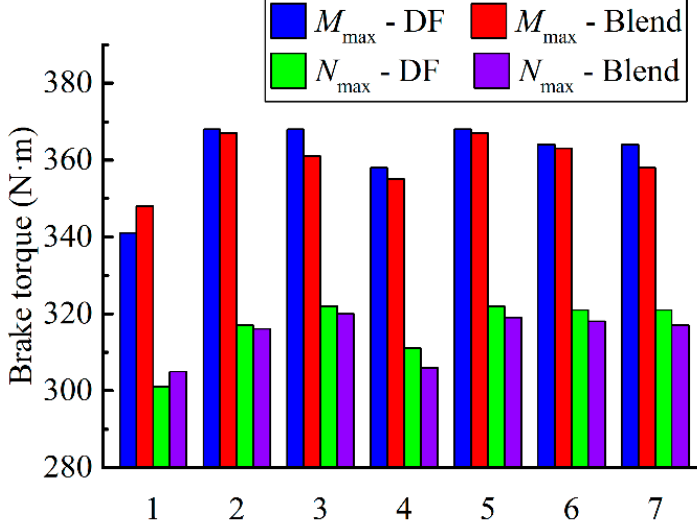

(b)

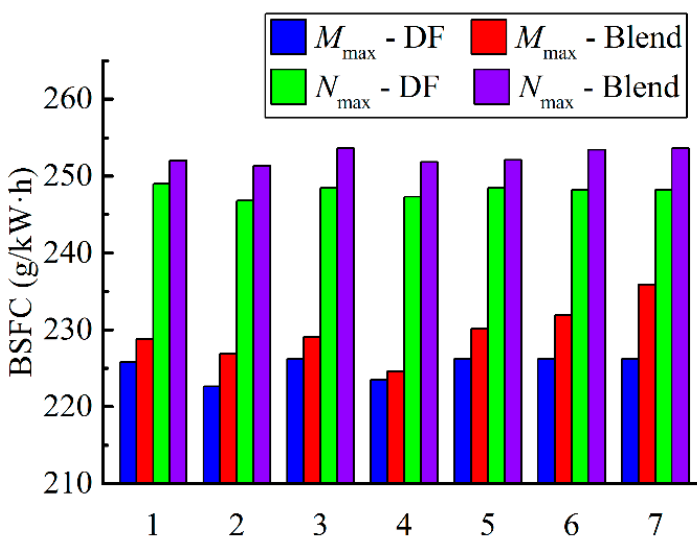

(d)

Figure 4. Main parameters of the diesel engine operating on petroleum DF and its blends with the investigated vegetable oils (1- $\mathrm{RO}, 2-\mathrm{SuO}, 3-\mathrm{SoO}, 4-\mathrm{CoO}, 5-\mathrm{LO}, 6-\mathrm{MO}, 7-\mathrm{CaO})$ in the maximum torque mode $\left(\mathrm{M}_{\max }\right)$ and in the maximum power mode $\left(N_{\max }\right)$ : (a)—brake power; (b)—brake torque; (c)—hourly fuel consumption; (d)—BSFC. 
Meanwhile, under the same operating conditions, the hourly consumption of the blended fuel increased by $3.03 \%$ and $4.71 \%$, respectively (Figure $4 \mathrm{c}$ ). A noticeable increase in the hourly fuel consumption-by $1.32 \%$ and $1.82 \%$, respectively-was also recorded with the addition of sunflower oil (Figure 4c). It should be noted that these vegetable oils have the highest kinematic viscosity among all of the investigated vegetable oils (Table 2): $75 \mathrm{~mm}^{2} / \mathrm{s}$ for rapeseed oil and $72 \mathrm{~mm}^{2} / \mathrm{s}$ for sunflower oil. With the addition of other vegetable oils, the increase in the hourly consumption of blended fuel is no more than $1.5 \%$ in comparison with petroleum DF. It should be noted that an increase in fuel consumption was recorded in almost all tests of biodiesel fuel.

The increase in the hourly fuel consumption and, consequently, in the fuel delivery per cycle (FDPC) under unchanged fuel equipment controls partially resulted from the $0.84-1.08 \%$ higher density of the blended fuels (Table 3 ). In addition, this was affected by the performance peculiarity of the fuel equipment running on the fuels with increased kinematic viscosity (Table 3 and Figure 1e). This effect is evidenced by the fact that in comparison with petroleum DF, a greater increase in the FDPC of the blended fuel was observed for the maximum torque modes at engine speeds of 1500 and $1600 \mathrm{rpm}$. At these speeds, the increased kinematic viscosity of the fuel contributes to reducing the fuel leakage through gaps of the high-pressure fuel pump compared to the maximum power mode (2400 rpm).

The variations in brake torque and FDPC cannot fully characterize the quality of the working process of the diesel engine when the investigated blended fuels are used. It is known that the quality of the fuel injection, fuel-air mixture formation, and combustion processes is manifested in the value of BSFC. As shown in Figure $4 d$, the use of a 10\% vegetable oil additive led to an increase in this indicator of the diesel engine fueled with all of the investigated blended fuels. However, the increase in BSFC for different blended fuels is significantly different (Figure 5). The smallest BSFC increases of $1.2 \%$ and $1.33 \%$ were achieved for RO-blended DF. The largest BSFC increases (from 2.1\% to $4.29 \%$ ) were observed for MO-blended DF and CaO-blended DF. Perhaps such a change in the efficiency of the working process is associated with the fatty acid composition of vegetable oils (Table 1). Interestingly, RO has a high content of unsaturated oleic acid (up to $60 \%$ ). MO and $\mathrm{CaO}$ have a low content of unsaturated oleic, linoleic, and linoleic acids (up to $18-24 \%$ for each acid). The other vegetable oils give an intermediate increase in BSFC and mainly contain unsaturated linoleic acid ( $\mathrm{SuO}-\mathrm{up}$ to $74 \%$, SoO-up to $59 \%$, $\mathrm{CoO}-$ up to $65.5 \%$ ) or unsaturated linolenic acid ( $\mathrm{LO}-$ up to $67 \%$ ). It can be assumed that the increased content of unsaturated fatty acids contributes to more active oxidation of the blended fuel.

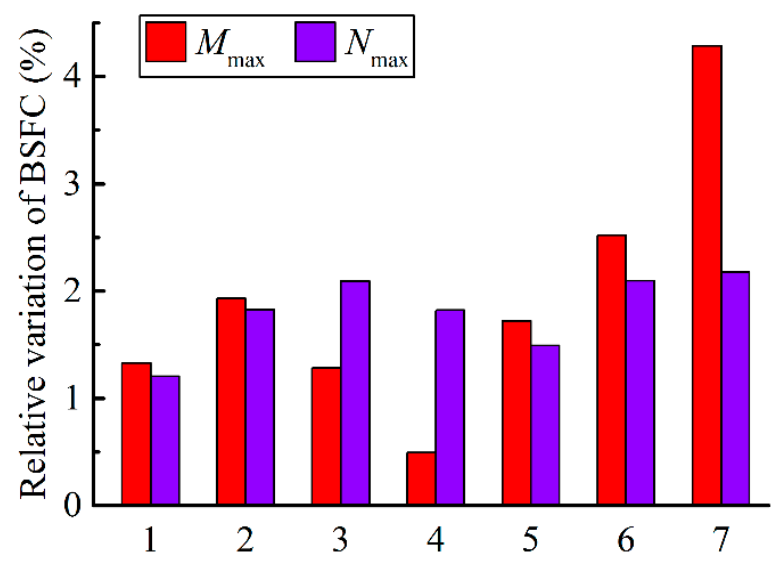

Figure 5. Relative variation of BSFC for the blended fuels compared to petroleum DF in the maximum torque mode $\left(M_{\max }\right)$ and in the maximum power mode $\left(N_{\max }\right)$ : $1-\mathrm{RO}$-blended $\mathrm{DF}, 2-\mathrm{SuO}$-blended DF, 3-SoO-blended DF, 4-CoO-blended DF, 5-LO-blended DF, 6-MO-blended DF, 7-CaOblended DF. 
It is worth noting that the inclusion of various acids with an increased oxygen content (from $10 \%$ to $11.1 \%$ ) in vegetable oils led to an increase in BSFC (by $0.4-4.3 \%$ ) due to a decrease in the calorific value of blended fuels (by 11.5-12.7\%) (Table 2). The influence of the increased oxygen content and the associated lower calorific value of vegetable oils on the increase in BSFC has been reported in a number of works by other authors $[1,24,32,33,39,48]$.

The measured results of exhaust emission indicators of the diesel engine D-245.12S running on the blended fuels containing $10 \%$ vegetable oils in the operating modes of maximum power and maximum torque (modes No. 6 and 8 in Figure 3) are presented in Tables 7 and 8 and in Figure 6 and Figure 8. As can be seen from them, the emissions of $\mathrm{NOx}, \mathrm{CO}$, and $\mathrm{HC}$ and, especially, the exhaust smoke $\left(K_{\mathrm{x}}\right)$ in the maximum torque mode in all tests at different test times were always significantly higher than those in the maximum power mode. This is typical for diesel engines that have a high-intensity working process and run in the operating conditions of the external characteristic curve [24,50].

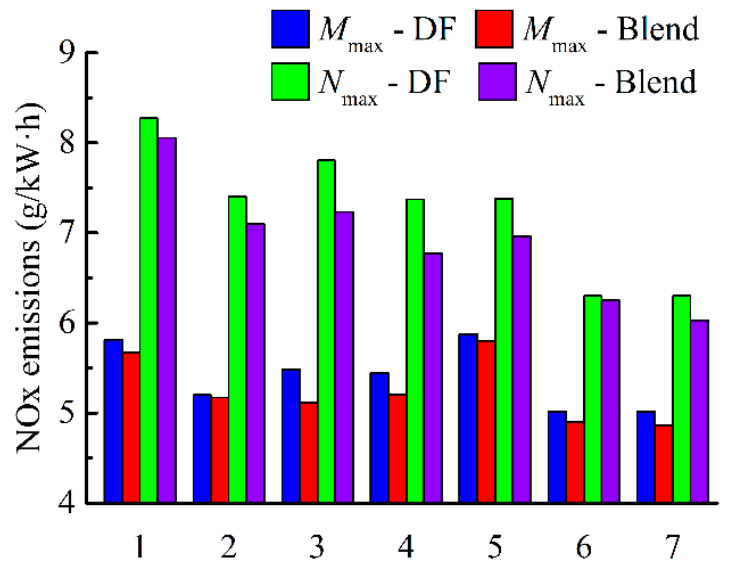

(a)

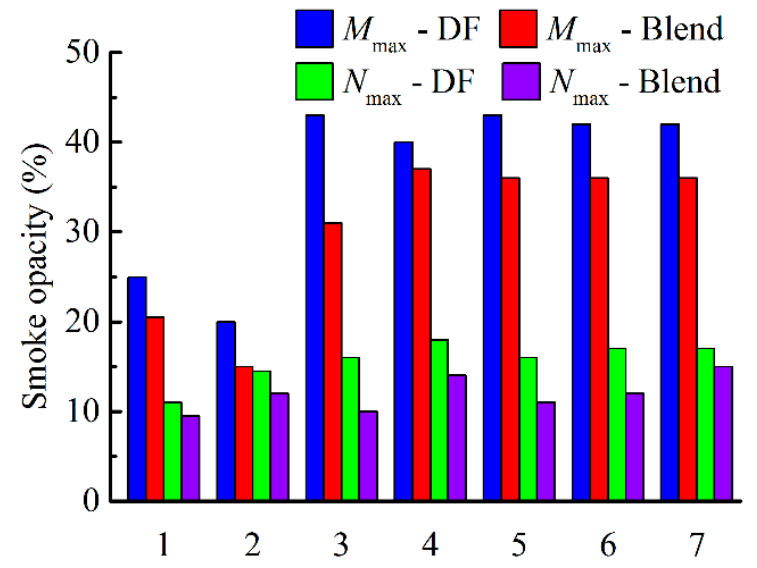

(b)

Figure 6. NOx emissions (a) and exhaust smoke opacity (b) for petroleum DF and its blends with vegetable oils (1-RO, $-\mathrm{SuO}, 3-\mathrm{SoO}, 4-\mathrm{CoO}, 5-\mathrm{LO}, 6-\mathrm{MO}, 7-\mathrm{CaO})$ in the maximum power mode $\left(N_{\max }\right)$ and in the maximum torque mode $\left(M_{\max }\right)$.

The use of a $10 \%$ vegetable oil additive led to a noticeable reduction in NOx emissions (Figure 6a) and a significant decrease in exhaust smoke (Figure 6b) for almost all of the blended fuels under unchanged fuel equipment controls. The relative reduction in NOx emissions was in the range of $0.9 \%$ to $8.3 \%$ ( $4.7 \%$ on average) in the maximum power mode (2400 rpm) and in the range of $0.7 \%$ to $7.1 \%(3.0 \%$ on average) in the maximum torque mode (1500 rpm and $1600 \mathrm{rpm}$ ) (Figure 7a). A slight decrease in NOx emissions attributed to the use of biodiesel was also obtained by other authors for blended diesel fuel with a biodiesel content up to $10 \%[22,65,67]$, up to $20 \%[4,48,58,67]$ and for agricultural diesel engines [51] and heavy-duty DI diesel engines [25].

The relative decrease in exhaust smoke opacity ranged from $11.8 \%$ to $37.5 \%(23.3 \%$ on average) in the maximum power mode (2400 rpm) and from $7.5 \%$ to $27.9 \%$ (17.6\% on average) in the maximum torque mode (1500 rpm and $1600 \mathrm{rpm}$ ) (Figure $7 \mathrm{~b}$ ). These data are consistent with the results of other authors, where the reduction in smoke emissions was recorded in the range of $11-16 \%$ to $50.95 \%$ [3,13,42,48,53,60,61,72].

As shown in Figure 8, it is obvious that the addition of $10 \%$ vegetable oils to petroleum DF resulted in a noticeable reduction in $\mathrm{CO}$ emissions(Figure $8 \mathrm{a}$ ) and $\mathrm{HC}$ emissions (Figure $8 \mathrm{~b}$ ). The relative reduction in CO emissions was in the range of $3.0 \%$ to $20 \%$ (Table 8$)(11.0 \%$ on average) in the maximum power mode (2400 rpm) and in the range of $7.6 \%$ to $15.2 \%(10.5 \%$ on average) in the maximum torque mode (1500 rpm and $1600 \mathrm{rpm}$ ) (Figure 9a). The reduction in $\mathrm{HC}$ emissions ranged from $8.3 \%$ to $24.4 \%$ (13.3\% on average) and from $10.8 \%$ to $27.9 \%$ 
( $18.2 \%$ on average) in the corresponding operating modes (Figure $9 \mathrm{~b}$ ). It should be noted that a decrease in $\mathrm{CO}$ and $\mathrm{CH}$ emissions was recorded in almost all tests of biodiesel fuel.

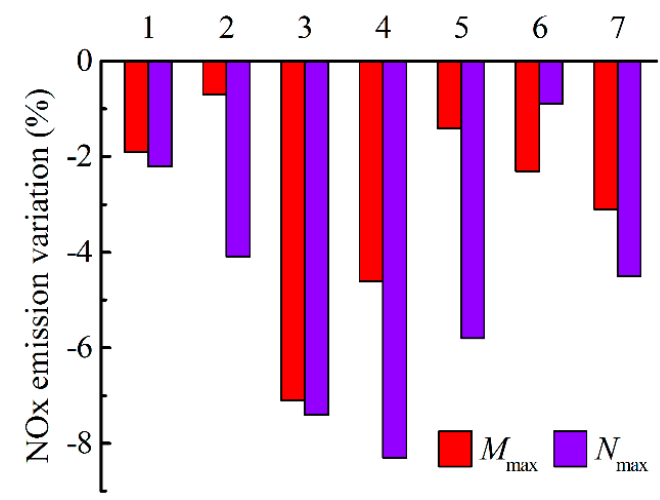

(a)

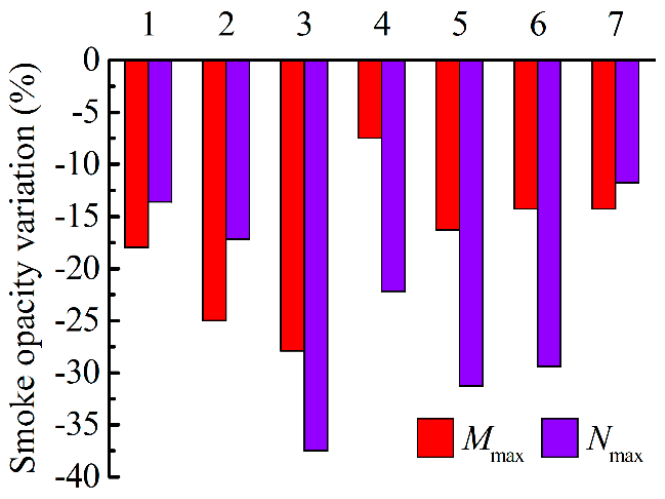

(b)

Figure 7. Relative variations of NOx emissions (a) and exhaust smoke opacity (b) for vegetable oil-blended DF compared to petroleum DF in the maximum power mode $\left(N_{\max }\right)$ and in the maximum torque mode $\left(M_{\max }\right)$ : $1-\mathrm{RO}-\mathrm{blended} \mathrm{DF}$, 2-SuO-blended DF, 3-SoO-blended DF, 4-CoO-blended DF, 5-LO-blended DF, 6-MO-blended DF, 7-CaO-blended DF.

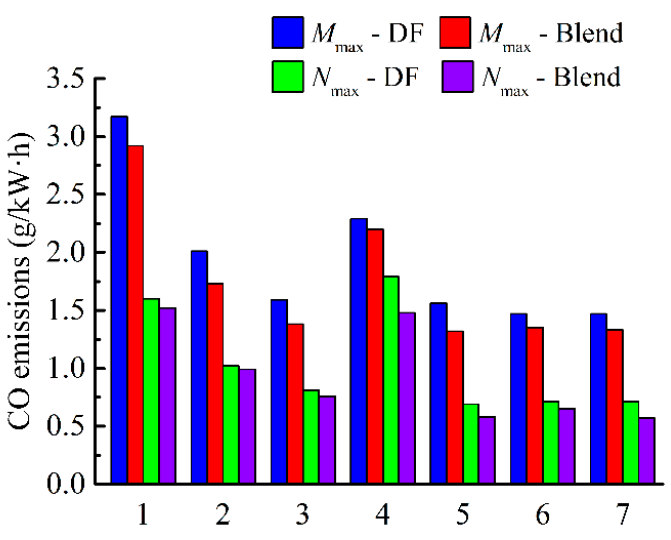

(a)

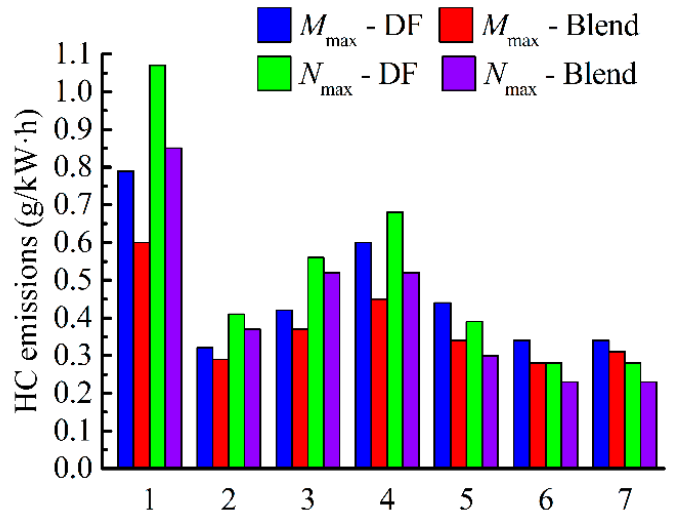

(b)

Figure 8. CO emissions (a) and $\mathrm{HC}$ emissions (b) for petroleum $\mathrm{DF}$ and its blends with vegetable oils $(1-\mathrm{RO}, 2-\mathrm{SuO}$, $-\mathrm{SoO}, 4-\mathrm{CoO}, 5-\mathrm{LO}, 6-\mathrm{MO}, 7-\mathrm{CaO})$ in the maximum power mode $\left(N_{\max }\right)$ and in the maximum torque mode $\left(M_{\max }\right)$.

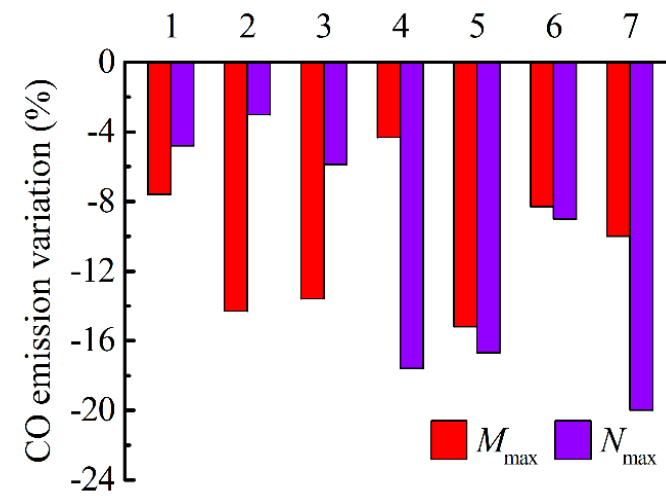

(a)

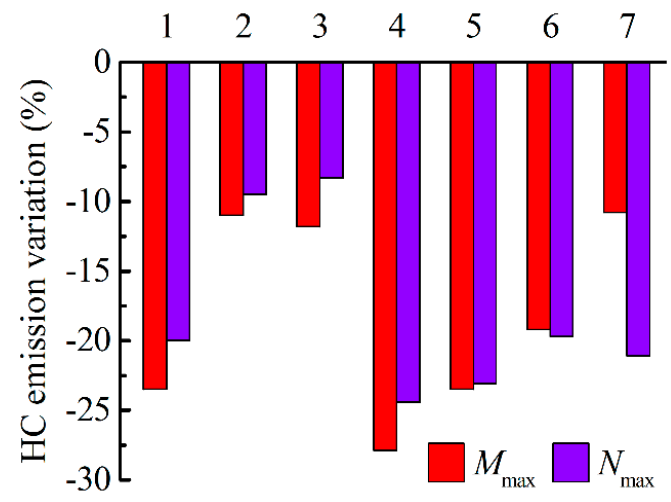

(b)

Figure 9. Relative variations of CO emissions (a) and HC emissions (b) for vegetable oil-blended DF compared to petroleum $\mathrm{DF}$ in the maximum power mode $\left(N_{\max }\right)$ and in the maximum torque mode $\left(M_{\max }\right)$ : 1 - RO-blended DF, 2-SuO-blended DF, 3-SoO-blended DF, 4-CoO-blended DF, 5-LO-blended DF, 6-MO-blended DF, 7-CaO-blended DF. 
The above-described reduction in emissions of harmful substances was achieved, undoubtedly, as a result of the improvement of the combustion process in the investigated diesel engine when an amount of $10 \%$ of different vegetable oils was added into petroleum DF. Analogous explanations are given by other authors [24,25]. This can be explained by the presence of a higher oxygen content in vegetable oils (Table 2) and by the weak bonds of oxygen atoms in fatty acid molecules, which facilitate their decomposition in the combustion chamber. The reduction in NOx emissions is also attributed to the decrease in the maximum temperature in the combustion chamber due to the fact that the calorific value of the investigated blended biofuels is 1.18 1.41\% lower than that of petroleum DF by $1.18-1.41 \%$. Attention is drawn to this in other works $[5,24,25]$.

\subsection{Test Results of the Diesel Engine D-245.12S in the Operating Conditions of the 13-Mode Steady-State Test Cycle (ECE R49)}

The integral (average) efficiency and emission parameters of the diesel engine D245.12S running on blends of petroleum DF with $10 \%$ vegetable oils in the European 13-mode steady-state test cycle (ECE R49) are shown in Table 9 and Figures 10 and 11. As shown in Figure 10a, the use of a 10\% vegetable oil additive led to an increase in the ABSFC for all of the blended fuels. However, this increase for different blended fuels is significantly different (Figure 11). The smallest increase in ABSFC from $1.39 \%$ to $1.73 \%$ was obtained for RO-blended DF (No. 1), SoS-blended DF (No. 3), CoO-blended DF (No. 4), and LO-blended DF (No. 5). The most significant increase in ABSFC was achieved for SuO-blended DF (No. 2) (by 6.75\%) and CaO-blended DF (No. 7) (by 4.47\%). It is possible that such an increase in the ABSFC for SuO-blended DF is due to the long-term operation of the diesel engine (32\% of the total operating time in Figure 3 ) in partial load modes at an increased speed of $1600 \mathrm{rpm}$ (Table 6). In comparison, the other blended fuels were tested in partial load modes at an increased speed of only $1500 \mathrm{rpm}$. As for CaO-blended $\mathrm{DF}$, the increase in BSFC in the main operating modes (in the maximum power mode and, especially, in the maximum torque mode) was also more than that for blended fuels with other vegetable oils (Figure 5).

As can be seen from Figure $10 \mathrm{~b}-\mathrm{d}$, the addition of $10 \%$ vegetable oils to petroleum DF caused a noticeable reduction in the IBSNOx, IBSCO, and IBSHC over the European 13-mode steady-state test cycle (ECE R49).

The most significant reduction in integral brake-specific emissions, mainly by 8.62-30.0\%, was recorded for IBSHC (Figure 11). The minimum reduction in IBSHC was provided only by the addition of SoO and was $3.3 \%$. The maximum reduction in IBSHC was achieved with the addition of $\mathrm{RO}(20.9 \%)$ and $\mathrm{CoO}(30.0 \%)$. For blends of petroleum DF with these two vegetable oils, the greatest reductions in HC emissions in the maximum power and maximum torque modes have also been observed (Figure 9b).

A significant reduction in IBSCO has been achieved. This reduction ranged from $4.3 \%$ for RO-blended DF to $15.0 \%$ for CaO-blended DF (Figure 11). The greatest reduction in IBSCO was obtained for CaO-blended DF (15.0\%), CoO-blended DF (13.8\%), and LOblended DF (12.3\%). Interestingly, similar results of $\mathrm{CO}$ emission reduction have been obtained in the maximum power mode (Figure 9a), where the greatest reduction has been found for CaO-blended DF (20.0\%), CoO-blended DF (17.6\%), and LO-blended DF (16.7\%).

When the diesel engine operated in the operating conditions of the European 13-mode steady-state test cycle (ECE R49), a reduction in IBSNOx of $1.9 \%$ to $16.0 \%$ was achieved with the addition of all vegetable oils except $\mathrm{SuO}$ (Figure 11). On the contrary, the addition of sunflower SuO to petroleum DF resulted in an increase in IBSNOx by $0.29 \%$. Perhaps this is also attributed to a significant increase in ABSFC (Figure 11) and the long-term operation of the diesel engine (32\% of the total operating time in Figure 3 ) in partial load modes at an increased speed of $1600 \mathrm{rpm}$ (Table 6). In comparison, the other blended fuels were tested in partial load modes at an increased speed of only $1500 \mathrm{rpm}$. 


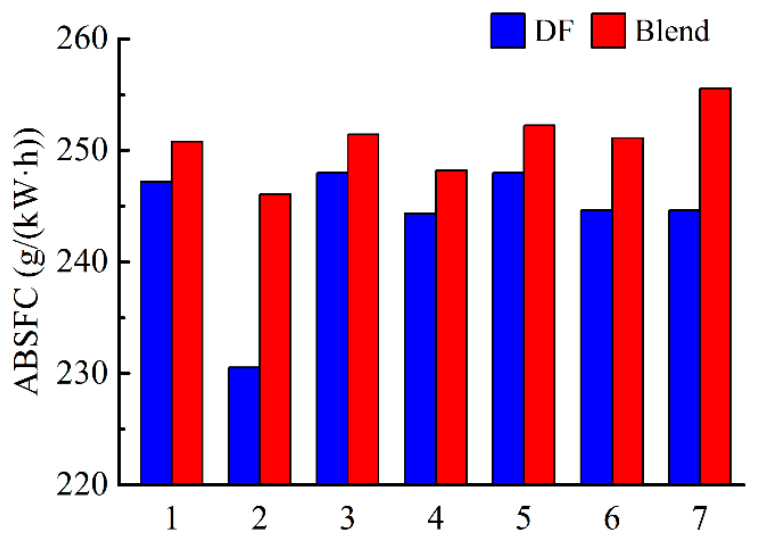

(a)

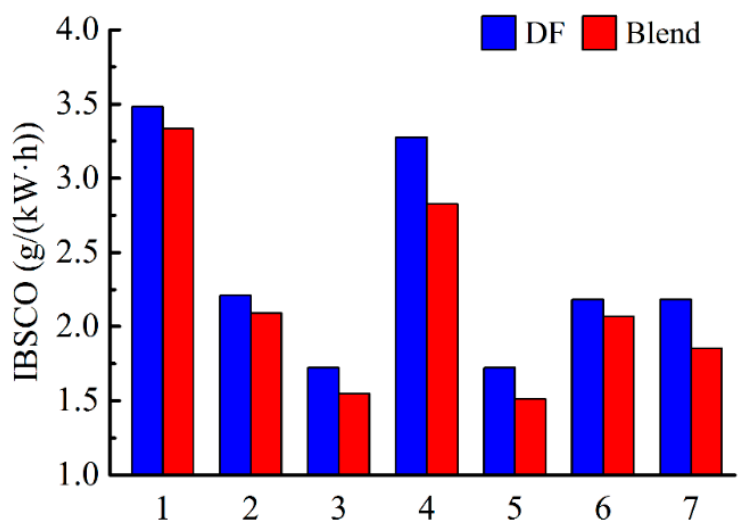

(c)

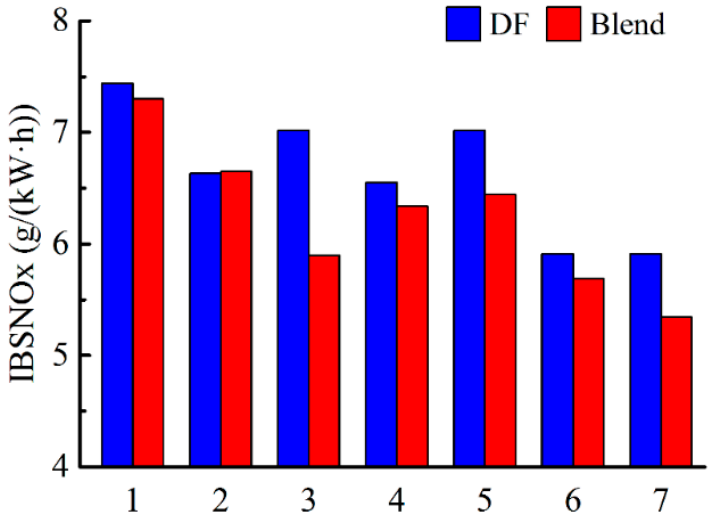

(b)

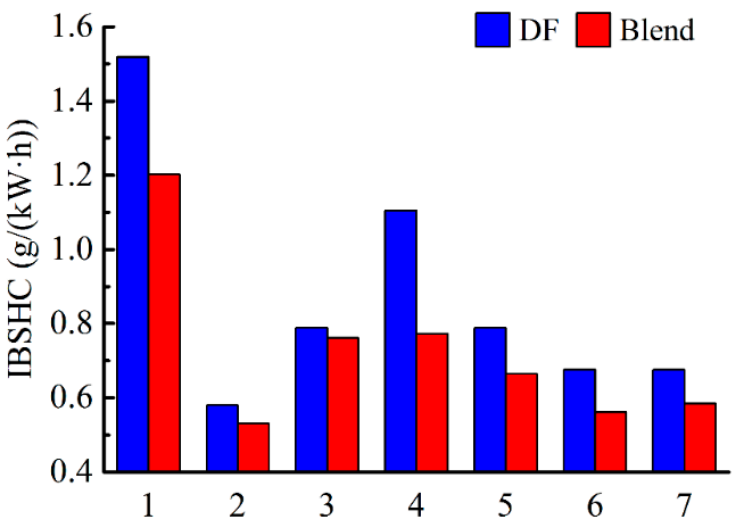

(d)

Figure 10. ABSFC (a), IBSNOx (b), IBSCO (c), and IBSHC (d) for petroleum DF and its blends with vegetable oils (1-RO, 2- $\mathrm{SuO}$, 3- $\mathrm{SoO}, 4-\mathrm{CoO}, 5-\mathrm{LO}, 6-\mathrm{MO}, 7-\mathrm{CaO}$ ) over the 13-mode test cycle.

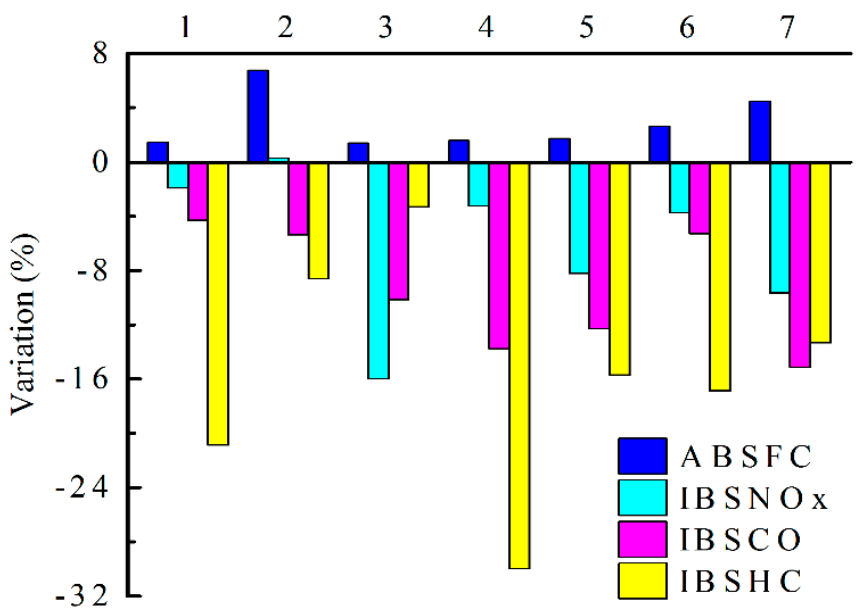

Figure 11. Relative variations of ABSFC, IBSNOx, IBSCO, and IBSHC for vegetable oil-blended DF compared to petroleum DF in the 13-mode test cycle: 1-RO-blended DF, 2-SuO-blended DF, 3-SoOblended DF, 4-CoO-blended DF, 5-LO-blended DF, 6-MO-blended DF, 7-CaO-blended DF.

The above analysis of the experimental results of the diesel engine D-245.12S in operating conditions of the European 13-mode steady-state test cycle (ECE R49) shows that the addition of $10 \%$ of the investigated vegetable oils to petroleum DF made it possible to reduce the pollution emissions of exhaust gases not only in the operating modes of 
maximum power and maximum torque. With the addition of different vegetable oils, IBSHC decreased by $3.3-30.0 \%$, IBSCO decreased by $4.3-15.0 \%$, and IBSNOx also decreased by $1.9-16.0 \%$ for all vegetable oils, except for SoO.

To summarize all of the comparative experimental studies, it can be stated that despite the significant differences in the physicochemical properties and composition diversity of the investigated vegetable oils, the use of any one of them as a $10 \%$ additive in blended biofuel will insignificantly affect the technical and economic indicators of the diesel engine D-245.12S for agricultural machinery and commercial vehicles, but will save fossil fuels and improve the harmful impact on the environment.

Therefore, the results of this study have indicated not only the possibility but also the rationality of using the investigated vegetable oils as a $10 \%$ additive in blended biofuel for diesel engines of agricultural machinery and commercial vehicles. However, it will be possible to recommend their wide application in practice after operational tests.

\section{Conclusions}

Based on the set of comparative experimental studies of the effect of adding $10 \%$ of one of seven different vegetable oils into petroleum DF on the technical, economic, and emission characteristics of one type of diesel engine, D-245.12S, for agricultural machinery and commercial vehicles, the following conclusions can be drawn.

1. All basic physicochemical properties of blended biofuels, consisting of $90 \%$ petroleum $\mathrm{DF}$ and $10 \%$ one of the vegetable oils, $\mathrm{RO}, \mathrm{SuO}, \mathrm{SoO}, \mathrm{CoO}, \mathrm{LO}, \mathrm{MO}, \mathrm{CaO}$, differ from the properties of petroleum DF by no more than $1-2.2 \%$. An exception is the kinematic viscosity of blended biofuels, which increases by 1.47-1.84 times. Small differences in the physicochemical properties of blended fuels allow all tests of the diesel engine D-245.12S to be carried out with unchanged fuel equipment controls.

2. In the operating modes of maximum power and maximum torque, the use of blended biofuels resulted in a drop in the engine brake power and a simultaneous increase in the hourly fuel consumption by no more than $1.5 \%$. An exception was RO-blended $\mathrm{DF}$, for which the brake torque increased by $1.33-2.05 \%$, accompanied by an increase in the hourly fuel consumption by $3.03 \%$ and $4.71 \%$ in the same modes. BSFC for all blended biofuels increased by $1.2-4.3 \%$.

3. The emissions of regulated harmful substances with the use of blended fuels were significantly reduced in the maximum power and maximum torque modes: NOx emissions—-by $0.7-8.3 \%$, exhaust smoke opacity—by $7.5-37.5 \%$, CO emissions—by $3.0-20.0 \%$, and HC emissions-by $8.3-27.9 \%$.

4. When the diesel engine was tested in the European 13-mode steady-state test cycle (ECE R49), reductions in IBSHC of 3.0-3.3\%, IBSCO of 4.3-15.0\%, and IBSNOx of $1.9-16.0 \%$ were also achieved. Only for SuO-blended DF did IBSNOx increase by $0.29 \%$. ABSFC increased over a wide range: from a minimum value of $1.39 \%$ for RO-blended DF to a maximum of $6.75 \%$ for SuO-blended DF.

5. The results obtained indicate the feasibility and rationality of using the investigated vegetable oils as a $10 \%$ additive in blended biofuel for diesel engines. This use will save fossil fuels and improve the harmful effect on the environment with a slight decrease in the technical and economic indicators of diesel engine D-245.12S for agricultural machinery and commercial vehicles.

Author Contributions: Conceptualization, V.M.; methodology, V.M. and V.K.; validation, S.D. and A.Z.; formal analysis, V.K. and A.Z.; investigation, V.K., S.D. and B.S.; resources, A.Z. and V.F.; data curation, V.M.; writing—original draft preparation, V.K. and B.S.; writing—review and editing, A.Z. and V.F.; visualization, B.S.; supervision, V.M.; project administration, V.M.; funding acquisition, V.F. All authors have read and agreed to the published version of the manuscript.

Funding: This research received no external funding.

Institutional Review Board Statement: Not applicable. 
Informed Consent Statement: Not applicable.

Data Availability Statement: Data sharing not applicable.

Conflicts of Interest: The authors declare no conflict of interest.

$\begin{array}{ll}\text { Abbreviations } \\ \text { DF } & \text { diesel fuel } \\ \text { RO } & \text { rapeseed oil } \\ \text { SuO } & \text { sunflower oil } \\ \text { SoO } & \text { soybean oil } \\ \text { CoO } & \text { corn oil } \\ \text { LO } & \text { linseed oil } \\ \text { MO } & \text { mustard oil } \\ \text { CaO } & \text { camelina oil } \\ \text { ABSFC } & \text { average brake-specific fuel consumption } \\ \text { BSFC } & \text { brake-specific fuel consumption } \\ \text { FDPC } & \text { fuel delivery per cycle } \\ \text { IBSCO } & \text { integral brake-specific carbon monoxide } \\ \text { IBSHC } & \text { integral brake-specific hydrocarbons } \\ \text { IBSNOx } & \text { integral brake-specific nitrogen oxides }\end{array}$

\section{References}

1. Singh, D.; Sharma, D.; Soni, S.L.; Inda, C.S.; Sharma, S.; Sharma, P.K.; Jhalani, A. A comprehensive review of physicochemical properties, production process, performance and emissions characteristics of 2nd generation biodiesel feedstock: Jatropha curcas. Fuel 2021, 285, 119110. [CrossRef]

2. Dey, S.; Reang, N.M.; Das, P.K.; Deb, M. A comprehensive study on prospects of economy, environment, and efficiency of palm oil biodiesel as a renewable fuel. J. Clean. Prod. 2021, 286, 124981. [CrossRef]

3. Simsek, S. Effects of biodiesel obtained from Canola, sefflower oils and waste oils on the engine performance and exhaust emissions. Fuel 2020, 265, 117026. [CrossRef]

4. Benjamin Franklin, S.; Arul, R. Experimental investigation on EGR technique and performance evaluation of diesel engine using diesel blend cotton seed oil as renewable fuel. Mater. Today Proc. 2020. [CrossRef]

5. Raman, L.A.; Deepanraj, B.; Rajakumar, S.; Sivasubramanian, V. Experimental investigation on performance, combustion and emission analysis of a direct injection diesel engine fuelled with rapeseed oil biodiesel. Fuel 2019, 246, 69-74. [CrossRef]

6. Yesilyurt, M.K.; Aydin, M.; Yilbasi, Z.; Arslan, M. Investigation on the structural effects of the addition of alcohols having various chain lengths into the vegetable oil-biodiesel-diesel fuel blends: An attempt for improving the performance, combustion, and exhaust emission characteristics of a compressi. Fuel 2020, 269, 117455. [CrossRef]

7. Murta, A.L.S.; De Freitas, M.A.V.; Ferreira, C.G.; Da Costa Lima Peixoto, M.M. The use of palm oil biodiesel blends in locomotives: An economic, social and environmental analysis. Renew. Energy 2021, 164, 521-530. [CrossRef]

8. Tun, M.M.; Juchelková, D. Biomass Sources and Energy Potential for Energy Sector in Myanmar: An Outlook. Resources 2019, 8, 102. [CrossRef]

9. Tun, M.M.; Juchelkova, D.; Win, M.M.; Thu, A.M.; Puchor, T. Biomass Energy: An Overview of Biomass Sources, Energy Potential, and Management in Southeast Asian Countries. Resources 2019, 8, 81. [CrossRef]

10. Yaşar, F. Comparision of fuel properties of biodiesel fuels produced from different oils to determine the most suitable feedstock type. Fuel 2020, 264, 116817. [CrossRef]

11. Raghuvaran, S.; Ashok, B.; Veluchamy, B.; Ganesh, N. Evaluation of performance and exhaust emission of C.I diesel engine fuel with palm oil biodiesel using an artificial neural network. Mater. Today Proc. 2021, 37, 1107-1111. [CrossRef]

12. Che Mat, S.; Idroas, M.Y.; Hamid, M.F.; Zainal, Z.A. Performance and emissions of straight vegetable oils and its blends as a fuel in diesel engine: A review. Renew. Sustain. Energy Rev. 2018, 82, 808-823. [CrossRef]

13. Rajak, U.; Verma, T.N. Effect of emission from ethylic biodiesel of edible and non-edible vegetable oil, animal fats, waste oil and alcohol in CI engine. Energy Convers. Manag. 2018, 166, 704-718. [CrossRef]

14. Rahman, S.M.A.; Fattah, I.M.R.; Maitra, S.; Mahlia, T.M.I. A ranking scheme for biodiesel underpinned by critical physicochemical properties. Energy Convers. Manag. 2021, 229, 113742. [CrossRef]

15. Çelikten, I.; Koca, A.; Ali Arslan, M. Comparison of performance and emissions of diesel fuel, rapeseed and soybean oil methyl esters injected at different pressures. Renew. Energy 2010, 35, 814-820. [CrossRef]

16. Elkelawy, M.; Alm-Eldin Bastawissi, H.; Esmaeil, K.K.; Radwan, A.M.; Panchal, H.; Sadasivuni, K.K.; Ponnamma, D.; Walvekar, R. Experimental studies on the biodiesel production parameters optimization of sunflower and soybean oil mixture and DI engine combustion, performance, and emission analysis fueled with diesel/biodiesel blends. Fuel 2019, 255, 115791. [CrossRef] 
17. Markov, V.A.; Kamaltdinov, V.G.; Zykov, S.A.; Savastenko, A.A. Multicomponent Biofuels for Agricultural Diesel Machines. J. Phys. Conf. Ser. 2019, 1260. [CrossRef]

18. Kanthasamy, S.; Karthick, A.; Ramalingam, V.; Praveen, M.V.J. Performance and emission characteristics of diesel engine fueled with ternary blends of linseed and rubber seed oil biodiesel. Fuel 2021, 285, 119255. [CrossRef]

19. Hoseini, S.S.; Najafi, G.; Ghobadian, B.; Rahimi, A.; Yusaf, T.; Mamat, R.; Sidik, N.A.C.; Azmi, W.H. Effects of biodiesel fuel obtained from Salvia macrosiphon oil (ultrasonic-assisted) on performance and emissions of diesel engine. Energy 2017, 131, 289-296. [CrossRef]

20. Madheshiya, A.K.; Vedrtnam, A. Energy-exergy analysis of biodiesel fuels produced from waste cooking oil and mustard oil. Fuel 2018, 214, 386-408. [CrossRef]

21. Sharma Dugala, N.; Singh Goindi, G.; Sharma, A. Evaluation of physicochemical characteristics of Mahua (Madhuca indica) and Jatropha (Jatropha curcas) dual biodiesel blends with diesel. J. King Saud Univ. Eng. Sci. 2020. [CrossRef]

22. Mirhashemi, F.S.; Sadrnia, H. NOX emissions of compression ignition engines fueled with various biodiesel blends: A review. J. Energy Inst. 2020, 93, 129-151. [CrossRef]

23. Hazrat, M.A.; Rasul, M.G.; Khan, M.M.K.; Ashwath, N.; Rufford, T.E. Emission characteristics of waste tallow and waste cooking oil based ternary biodiesel fuels. Energy Procedia 2019, 160, 842-847. [CrossRef]

24. Lešnik, L.; Biluš, I. The effect of rapeseed oil biodiesel fuel on combustion, performance, and the emission formation process within a heavy-duty DI diesel engine. Energy Convers. Manag. 2016, 109, 140-152. [CrossRef]

25. Lešnik, L.; Iljaž, J.; Hribernik, A.; Kegl, B. Numerical and experimental study of combustion, performance and emission characteristics of a heavy-duty DI diesel engine running on diesel, biodiesel and their blends. Energy Convers. Manag. 2014, 81, 534-546. [CrossRef]

26. Bari, S.; Hossain, S.N. Performance and emission analysis of a diesel engine running on palm oil diesel (POD). Energy Procedia 2019, 160, 92-99. [CrossRef]

27. Ellappan, S.; Rajendran, S. A comparative review of performance and emission characteristics of diesel engine using eucalyptusbiodiesel blend. Fuel 2021, 284, 118925. [CrossRef]

28. Osei, I.; Akowuah, J.O.; Kemausuor, F. Techno-Economic Models for Optimised Utilisation of Jatropha curcas Linnaeus under an Out-Grower Farming Scheme in Ghana. Resources 2016, 5, 38. [CrossRef]

29. Kanth, S.; Debbarma, S. Comparative performance analysis of diesel engine fuelled with hydrogen enriched edible and non-edible biodiesel. Int. J. Hydrog. Energy 2021, 46, 10478-10493. [CrossRef]

30. Botia, G.P.; Ochoa, G.V.; Forero, J.D. Characterization of emissions in a diesel engine using biodiesel blends produced from agro-industrial residues of Elaeis Guineensis. Int. J. Energy Convers. 2020, 8, 45-52. [CrossRef]

31. Manieniyan, V.; Velumani, V.; Senthilkumar, R.; Sivaprakasam, S. Effect of EGR (exhaust gas recirculation) in diesel engine with multi-walled carbon nanotubes and vegetable oil refinery waste as biodiesel. Fuel 2021, 288, 119689. [CrossRef]

32. Rajak, U.; Verma, T.N. A comparative analysis of engine characteristics from various biodiesels: Numerical study. Energy Convers. Manag. 2019, 180, 904-923. [CrossRef]

33. Simsek, S.; Uslu, S. Comparative evaluation of the influence of waste vegetable oil and waste animal oil-based biodiesel on diesel engine performance and emissions. Fuel 2020, 280, 118613. [CrossRef]

34. Tsai, W.-T. Mandatory Recycling of Waste Cooking Oil from Residential and Commercial Sectors in Taiwan. Resources 2019, 8, 38. [CrossRef]

35. Nirmala, N.; Dawn, S.S.; Harindra, C. Analysis of performance and emission characteristics of Waste cooking oil and Chlorella variabilis MK039712.1 biodiesel blends in a single cylinder, four strokes diesel engine. Renew. Energy 2020, 147, 284-292. [CrossRef]

36. Gao, Y.; Chen, Y.; Gu, J.; Xin, Z.; Sun, S. Butyl-biodiesel production from waste cooking oil: Kinetics, fuel properties and emission performance. Fuel 2019, 236, 1489-1495. [CrossRef]

37. Simsek, S.; Uslu, S. Determination of a diesel engine operating parameters powered with canola, safflower and waste vegetable oil based biodiesel combination using response surface methodology (RSM). Fuel 2020, 270, 117496. [CrossRef]

38. Gnanasekaran, S.; Saravanan, N.; Ilangkumaran, M. Influence of injection timing on performance, emission and combustion characteristics of a DI diesel engine running on fish oil biodiesel. Energy 2016, 116, 1218-1229. [CrossRef]

39. Sanli, H. An experimental investigation on the usage of waste frying oil-diesel fuel blends with low viscosity in a Common Rail DI-diesel engine. Fuel 2018, 222, 434-443. [CrossRef]

40. de Almeida D’Agosto, M.; da Silva, M.A.V.; Franca, L.S.; de Oliveira, C.M.; Alexandre, M.O.L.; da Costa Marques, L.G.; Murta, A.L.S.; de Freitas, M.A.V. Comparative study of emissions from stationary engines using biodiesel made from soybean oil, palm oil and waste frying oil. Renew. Sustain. Energy Rev. 2017, 70, 1376-1392. [CrossRef]

41. Vieira da Silva, M.A.; Lagnier Gil Ferreira, B.; da Costa Marques, L.G.; Lamare Soares Murta, A.; Vasconcelos de Freitas, M.A. Comparative study of NOx emissions of biodiesel-diesel blends from soybean, palm and waste frying oils using methyl and ethyl transesterification routes. Fuel 2017, 194, 144-156. [CrossRef]

42. Gad, M.S.; El-Shafay, A.S.; Abu Hashish, H.M. Assessment of diesel engine performance, emissions and combustion characteristics burning biodiesel blends from jatropha seeds. Process. Saf. Environ. Prot. 2021, 147, 518-526. [CrossRef]

43. Mendoza-Casseres, D.; Valencia-Ochoa, G.; Duarte-Forero, J. Experimental assessment of combustion performance in lowdisplacement stationary engines operating with biodiesel blends and hydroxy. Therm. Sci. Eng. Prog. 2021, 23, 100883. [CrossRef]

44. Madiwale, S.; Karthikeyan, A.; Bhojwani, V. Properties investigation and performance analysis of a diesel engine fuelled with Jatropha, Soybean, Palm and Cottonseed biodiesel using Ethanol as an additive. Mater. Today Proc. 2018, 5, 657-664. [CrossRef] 
45. Shote, A.S.; Betiku, E.; Asere, A.A. Characteristics of CO and NOx emissions from combustion of transmethylated palm kernel oil-based biodiesel blends in a compression ignition engine. J. King Saud Univ. Eng. Sci. 2019, 31, 178-183. [CrossRef]

46. Senthur Prabu, S.; Asokan, M.A.; Prathiba, S.; Ahmed, S.; Puthean, G. Effect of additives on performance, combustion and emission behavior of preheated palm oil/diesel blends in DI diesel engine. Renew. Energy 2018, 122, 196-205. [CrossRef]

47. Pipitone, E.; Costanza, A. An experimental investigation on the long-term compatibility of preheated crude palm oil in a large compression ignition diesel engine. Biofuel Res. J. 2018, 5, 900-908. [CrossRef]

48. Shrivastava, P.; Verma, T.N.; Pugazhendhi, A. An experimental evaluation of engine performance and emisssion characteristics of CI engine operated with Roselle and Karanja biodiesel. Fuel 2019, 254, 115652. [CrossRef]

49. Roy, M.M.; Islam, M.S.; Alam, M.N. Biodiesel from Crude Tall Oil and Its NOx and Aldehydes Emissions in a Diesel Engine Fueled by Biodiesel-Diesel Blends with Water Emulsions. Processes 2021, 9, 126. [CrossRef]

50. Reza Miri, S.M.; Mousavi Seyedi, S.R.; Ghobadian, B. Effects of biodiesel fuel synthesized from non-edible rapeseed oil on performance and emission variables of diesel engines. J. Clean. Prod. 2017, 142, 3798-3808. [CrossRef]

51. Patel, C.; Tiwari, N.; Agarwal, A.K. Experimental investigations of Soyabean and Rapeseed SVO and biodiesels on engine noise, vibrations, and engine characteristics. Fuel 2019, 238, 86-97. [CrossRef]

52. Markov, V.; Kamaltdinov, V.; Bykovskaya, L.; Sa, B. Performance of a diesel engine running on mixed biofuels with the addition of gasoline. E3S Web Conf. 2019, 140. [CrossRef]

53. Markov, V.A.; Devyanin, S.N.; Bowen, S. Emission Performance of a Diesel Engine Running on Petroleum Diesel Fuel with Different Vegetable Oil Additives. In Proceedings of the 2020 International Multi-Conference on Industrial Engineering and Modern Technologies (FarEastCon), Vladivostok, Russian, 6-9 October 2020; pp. 1-5. [CrossRef]

54. Roy, M.M.; Wang, W.; Bujold, J. Biodiesel production and comparison of emissions of a DI diesel engine fueled by biodiesel-diesel and canola oil-diesel blends at high idling operations. Appl. Energy 2013, 106, 198-208. [CrossRef]

55. Qi, D.H.; Lee, C.F.; Jia, C.C.; Wang, P.P.; Wu, S.T. Experimental investigations of combustion and emission characteristics of rapeseed oil-diesel blends in a two cylinder agricultural diesel engine. Energy Convers. Manag. 2014, 77, 227-232. [CrossRef]

56. Qi, D.H.; Bae, C.; Feng, Y.M.; Jia, C.C.; Bian, Y.Z. Combustion and emission characteristics of a direct injection compression ignition engine using rapeseed oil based micro-emulsions. Fuel 2013, 107, 570-577. [CrossRef]

57. Valente, O.S.; da Silva, M.J.; Pasa, V.M.D.; Belchior, C.R.P.; Sodré, J.R. Fuel consumption and emissions from a diesel power generator fuelled with castor oil and soybean biodiesel. Fuel 2010, 89, 3637-3642. [CrossRef]

58. Azizzadeh Hajlari, S.; Najafi, B.; Faizollahzadeh Ardabili, S. Castor oil, a source for biodiesel production and its impact on the diesel engine performance. Renew. Energy Focus 2019, 28, 1-10. [CrossRef]

59. Qi, D.; Xing, W.; Luo, P.; Liu, J.; Chen, R. Effect of alcohols on combustion characteristics and particle size distribution of a diesel engine fueled with diesel-castor oil blended fuel. Asia-Pacific J. Chem. Eng. 2020, 15, e2477. [CrossRef]

60. Uyumaz, A. Combustion, performance and emission characteristics of a DI diesel engine fueled with mustard oil biodiesel fuel blends at different engine loads. Fuel 2018, 212, 256-267. [CrossRef]

61. Markov, V.A.; Kamaltdinov, V.G.; Zykov, S.A.; Sa, B. Optimization of the composition of blended biodiesel fuels with additives of vegetable oils. Int. J. Energy Clean Environ. 2019, 20, 303-319. [CrossRef]

62. Markov, V.A.; Kamaltdinov, V.G.; Loboda, S.S. Using Mustard Oil as Ecological Additive to Petroleum Diesel Fuel. In Proceedings of the International Conference Actual Issues of Mechanical Engineering, Tomsk, Russia, 27-29 July 2017; Atlantis Press: Dordrecht, The Netherlands, 2017; pp. 484-489.

63. Viswanathan, K.; Ashok, B.; Pugazhendhi, A. Comprehensive study of engine characteristics of novel biodiesel from curry leaf (Murraya koenigii) oil in ceramic layered diesel engine. Fuel 2020, 280, 118586. [CrossRef]

64. Praveena, V.; Leenus Jesu Martin, M.; Edwin Geo, V. Effect of EGR on emissions of a modified DI compression ignition engine energized with nanoemulsive blends of grapeseed biodiesel. Fuel 2020, 267, 117317. [CrossRef]

65. Markov, V.A.; Kamaltdinov, V.G.; Savastenko, A.A. Petroleum Diesel Fuel and Linseed Oil Mixtures as Engine Fuels. J. Phys. Conf. Ser. 2018, 944, 12077. [CrossRef]

66. Hazar, H.; Sevinc, H. Investigation of the effects of pre-heated linseed oil on performance and exhaust emission at a coated diesel engine. Renew. Energy 2019, 130, 961-967. [CrossRef]

67. Markov, V.A.; Kamaltdinov, V.G.; Loboda, S.S. Optimization of Diesel Fuel and Corn Oil Mixtures Composition. Procedia Eng. 2016, 150, 225-234. [CrossRef]

68. Gaglio, M.; Tamburini, E.; Lucchesi, F.; Aschonitis, V.; Atti, A.; Castaldelli, G.; Fano, E.A. Life Cycle Assessment of Maize-Germ Oil Production and the Use of Bioenergy to Mitigate Environmental Impacts: A Gate-To-Gate Case Study. Resources 2019,8 , 60. [CrossRef]

69. Pizzi, A.; Duca, D.; Rossini, G.; Fabrizi, S.; Toscano, G. Biofuel, Bioenergy and Feed Valorization of By-Products and Residues from Hevea brasiliensis Cultivation to Enhance Sustainability. Resources 2020, 9, 114. [CrossRef]

70. Creencia, E.C.; Nillama, J.A.P.; Librando, I.L. Microwave-Assisted Extraction and Physicochemical Evaluation of Oil from Hevea brasiliensis Seeds. Resources 2018, 7, 28. [CrossRef]

71. Jain, N.L.; Soni, S.L.; Poonia, M.P.; Sharma, D.; Srivastava, A.K.; Jain, H. Performance and emission characteristics of preheated and blended thumba vegetable oil in a compression ignition engine. Appl. Therm. Eng. 2017, 113, 970-979. [CrossRef]

72. Kotaiah, K.; Periyasamy, P.; Prabhahar, M. Performance and emission characteristics of small agricultural diesel engine using Lemongrass oil and its diesel blends. Mater. Today Proc. 2020, 33, 658-662. [CrossRef] 
73. Qi, D.H.; Yang, K.; Zhang, D.; Chen, B.; Wei, Q.; Zhang, C.H. Experimental investigation of a turbocharged CRDI diesel engine fueled with Tung oil-diesel-ethanol microemulsion fuel. Renew. Energy 2017, 113, 1201-1207. [CrossRef]

74. EL-Seesy, A.I.; He, Z.; Hassan, H.; Balasubramanian, D. Improvement of combustion and emission characteristics of a diesel engine working with diesel/jojoba oil blends and butanol additive. Fuel 2020, 279, 118433. [CrossRef]

75. Food and Agriculture Organization; World Health Organization. Codex Alimentarius, Volume 8: Fats, Oils and Related Products, 2nd ed.; Food and Agriculture Organization of the United Nations (FAO): Rome, Italy, 2001; ISBN 9251046824. 